
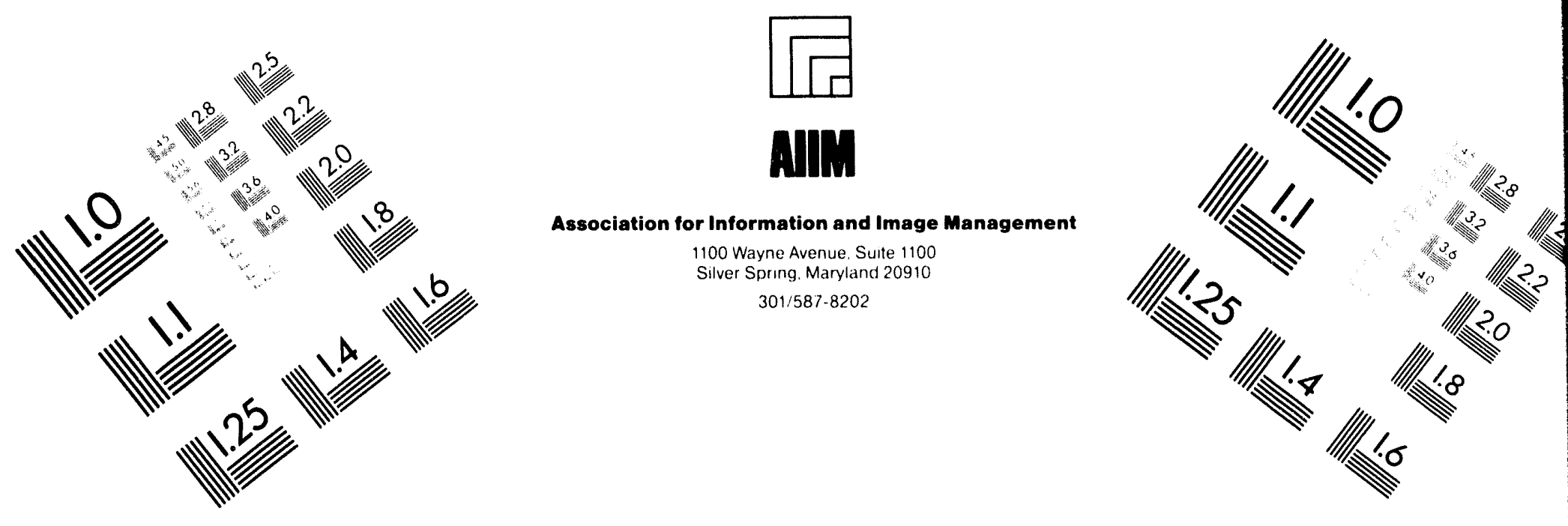

\title{
Centimeter
}

|

Inches
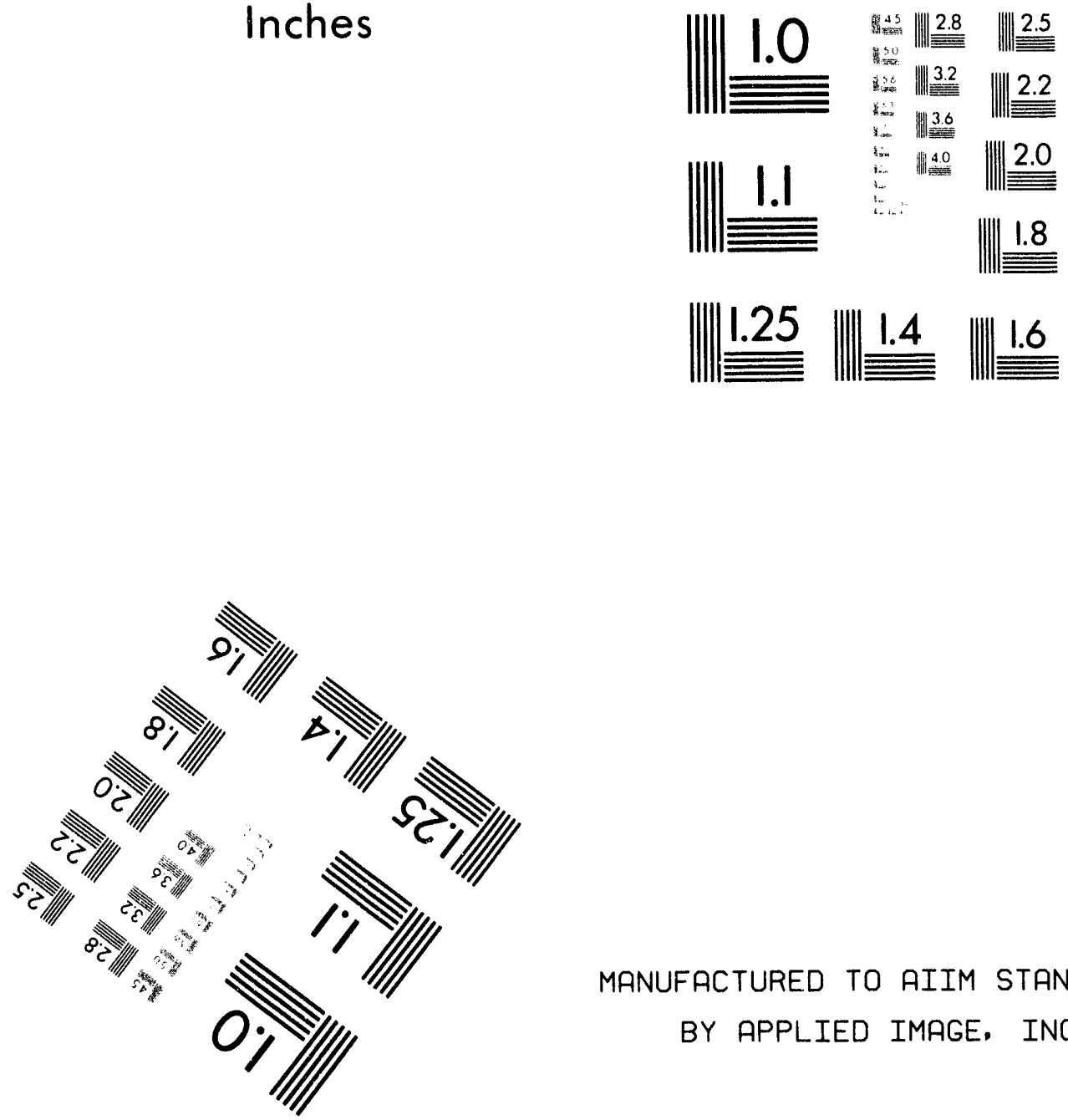

MANUFACTURED TO AIIM STANDARDS

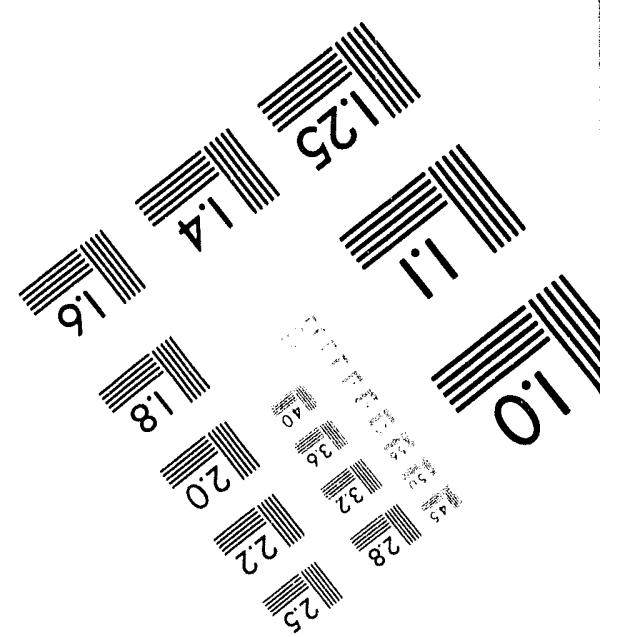



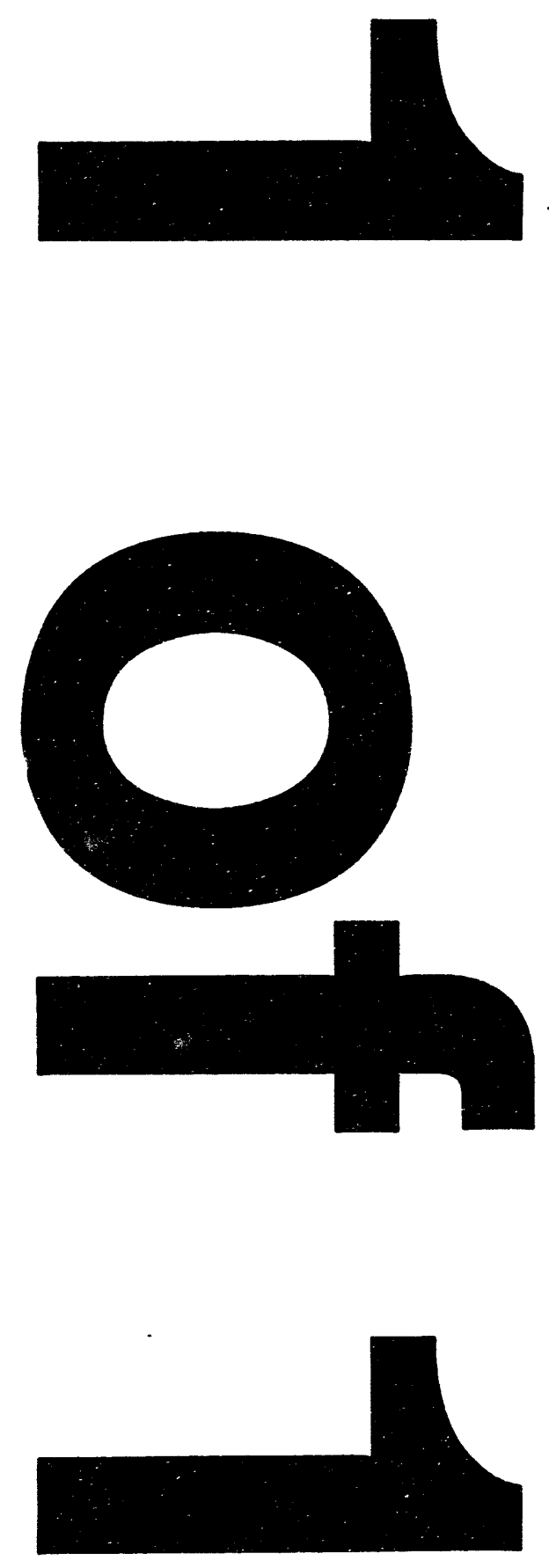


\section{A Warm and Wet Little Climatic Optimum and a Cold and Dry Little Ice Age in the Southern Rocky Mountains, U.S.A.}

Prepared for the U.S. Department of Energy

Office of Environmental Restoration and

Waste Management

(2) Hesting thoure

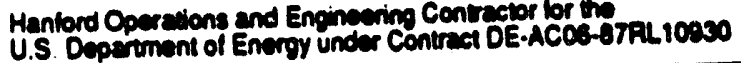

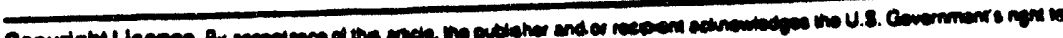

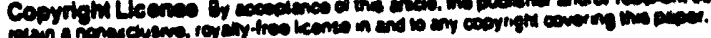

Approved for Public Release 
LEGAL OISCLAMEA

This report was prepared as an account of wopk sponsored by an agency of the Uniled States Government. Neither the United Stales Government not any aponey thereol. nor any of their amployees. nor any of thair coniractors. subcontractors or their omployees, makes any warraniy. oxpress of implied. of assumes any logal liablity or responsibiliry for the accuracy, complotoness. or any inird party's use or ine results of such use ol any information, apparatus. product, or procoss disclosed, of represents that its use would nol intringe privately owned righis. Relorence horein wo any speeffic commercial product, process, of semice by trade name. Irademark, manulacturer, or ornerwise, does nol nocassarily constitute or imply its ondorsement, recommendation, of lavoring by the United States Government or sny ageney inoreol of its contrestors or eubcontractors. The viows and opinions of authors expressed horein do not nocessanly stato of refloct those of tho United Stalos Governmont of any agency thereol.

This roport has been reproduced from the best available copy.

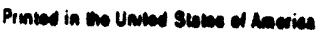

OIsctin-2.CHP (1.01)

$\cdots:$

$\pi$

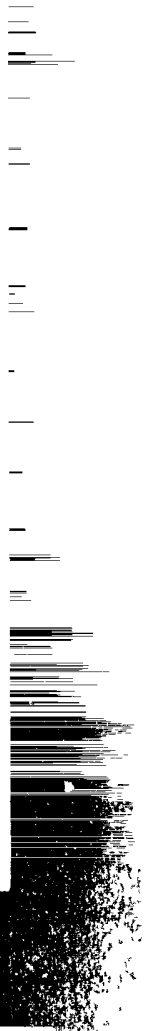


WHC.SA-1382-FP

\title{
A Warm and Wet Little Climatic Optimum and a Cold and Dry Little Ice Age in the Southern Rocky Mountains, U.S.A.
}

\author{
RECEIVED
JUN $0>1994$ \\ OSTI
}

K. L. Petersen

Date Published

May 1992

Prepared for the U.S. Department of Energy Office of Environmental Restoration and Waste Management

(29) Wastingtruas P.o. Box 1970

Hantord Operradons and Encinewing Contrector tor the

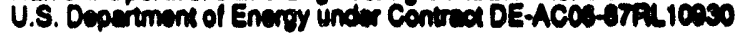

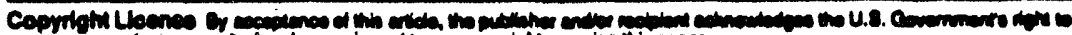

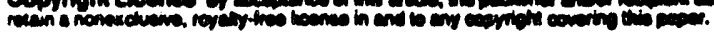

Approved for Public Release 
WHC-SA-1382-FP

A WARM AND HET LITTLE CLIMATIC OPTIMUM ANO A COLD ANO DRY LITTLE ICE AGE IN THE SOUTHERN ROCKY MOUNTAINS, U.S.A.

KENNETH LEE PETERSEN

Westinghouse Hanfond Company, P.O. Box 1970, Mall Stop H4-14, Richland, W.A 99352

Abstract. The zenith of Anasazl Pueblo Indtan occupation in the northern Colorado Plateau region of the southwestern U.S.A. coincides with the Little Climatic Optimum or Medieval Warm Perlod (AD 900-1300), and its demise coincides with the commenc sent of the Little Ice Age. Indexes of winter (jet-stream derived) and sumer (monsoon derived) precipitation and growing season length were developed for the La Plata Mountains region of southwestern Colorado. The results show that during the height of the Little Climatic Optimum (AD 1000-1100) the region was characterized by a relatively long growing season and by a potential dry farming zone or elevational belt (currently located between 2,000 $m$ and 2,300 m elevation) that was twice as wide as present and could support Anasazi upland dry farming down to at least $1,600 \mathrm{~m}$, an elevation that is quite impossible to dry farm today because of insufficient soll moisture. This expanded dry-farm belt is attributable to a more vigorous circulation regine characterized by both greater winter and sumer precipitation than that of today. Between AD 1100 and 1300 the potential dry-farm belt narrowed and finally disappeared with the onset of a perlod of markedly colder and drfer conditions than currently exist. Finally, when the Little Ice Age terminated in the aid AD 1800 s 
WHC-SA-1382-FP

and warmer, wetter conditions returned to the regton, another group of farmers (modern Anglos) were able to dry farm the area.

1. Introduction

According to the greenhouse theory, during the next decades and centurfes global climatic variation will exceed the historical records as the lower atmosphere warms in response to a rise in concentrations of carbon dioxide, methane, and other gases (Houghton et $1 ., 1990$ ). The sharp contrast between the large predicted future change and the small climatic changes of the last century indicates that this latter period may offer an insufficient basis for appreciating the projected future climate and vegetation changes. Examination of larger-than-historic climatic changes that have occurred in the past, in specific locations, may provide a context for evaluating possible future changes (Schneider, 1986).

Anyone visiting the prehistoric ruins in the American Southwest leaves with a sense of respect for the ancient dwellers, the construction of their dwellings, and the balance they achieved with nature. The latter aspect is particularly interesting because these ancient people relied so heavily on agriculture in an area recognized for its arid climate and, in some regions, relatively high elevation. The earliest populations that are dated before the time of Christ were originally hunters and gatherers, but during the last 2,000 yr they have evolved into three culturally distinct traditions upon stimulus from Mexico. These include the Mogollon or Western Pueblo, the descendent and more widespread Anasazi Pueblo of the northern Southwest, and the regionaliy restricted Hohokam culture, which was confined to the Salt and 
Gila River drainages of southern Arizona. By A.D. 900 (Figure 1). these cultural traditions had developed advanced and flourishing socletles, farming corn, beans, and squash; and supplementing their diet by hunting and gathering or raising food, such as turkeys.

By A.D. 1100 the Anasazl (which, in this case, also includes the corngrowing Fremont and Sevier-Fremont groups of present-day Utah) had reached the ir most northern extension. Around A.D. 1200, long before any Europeans -or even the Navajo or Apache Indians -- arrived in the region, the Anasazi began to abandoned most of their former northern territory (currently Colorado and Utah). At the same time, the population in the Rio Grand Valley began to expand rapidly, probably from migration, and it ccistinued to grow unt 11 its peak at about A.D. 1300 . Other Anasazi groups migrated to parts of Arizona. By A.D. 1300, the area of Utah and Colorado no longer had evidence of Indian farmers growing corn, suggesting the region had been vacated and during the succeeding several centuries the population of the remaining territory was reduced as other Indian groups and Europeans moved into the southwest United States. However, the Anasazi did not disappear; they probably were assimilated by the Hopi, Zuni, and other modern Pueblo Indians of northern Arizona and New Mexico, some of which still exist today.

The zenith of Anasazi Pueblo Indian occupation coincides with the Little Climatic Optimum (Medieval Warm Period) of Europe (A.D. 900 - 1300), a time of purported elevated temperatures compared to those of the present (Lamb, 1977). However, the exact nature of the climate and vegetation manifested in the four Corners region (where Utah, Colorado, Arizona, and New Mexico meet) during that time has received only cursory quantification. However, the precarious nature of farming in the four Corners region has led many researchers to 
WHC-SA-1382-FP

hypothosize that any severe climatic deterioration in the past may have affected the Anasazt's abtlity to grow corn the same way that it could affect efforts today (see Gumerman, 1988, and references therein).

During recent decades, many sctentists have maintained, on the basts of tree-ring evtdence, that drought forced the Anasazt from the Four Corners region. However, other scientists refer to indications that there had been earlier droughts that were as serious, yet the Anasazi did not leave during those droughts (Fritts et al., 1965). Som researchers (e.g.. Berlin at al.. 1977; Bryson and Julian, 1963; Martin and Byers, 1965; Smiley, 1961; Woodbury 1961) have suggested that the demise of the Anasazi culture may coincide with the onset of the Little Ice Age, a time of colder temperatures than the present (Grove, 1988). In many parts of the world, the Little Ice Age has been described as a time of renewed glacial activity, expanding snowflelds and, in some regions, reduced summer monsoons. However, the evidence for the timing, severity, and exact nature of that climatic episode in the four Corners region generally is unknown.

Presented here is a specific case study of the Anasazi Pueblo Indtans' farmers of the Four Corners region of the southwest Untted States, focusing on the timing, nature, and range of climatic and vegetation change coincident with the Anasazi occupation and abandonment of that high plateau region. The research sumarized here began in 1972 in conjunction with the Salmon Ruins Archaeological Project (northeast New Mexico) and continued as part of the archaeological mitigation effort (1978 - 1985) necessitated by the U.S. Bureau of Reclamation's construction of the McPhee Daw and Reservoir on the Dolores River in southwest Colorado (Breternitz et al., 1986; Petersen and Mehringer, 1976; Petersen et al., 1985; Petersen et al., 1987; Petersen, 1988a). 
WHC-SA-1382-FP

\section{The La Plata Nountains Regtonal Environent}

The La Plata Mountains of southwestern Colorado are a remote and plcturasque mountain group that protrudes into the eastern edge of the Colorado Plateau $30 \mathrm{~km}$ southwest of the main San Juan Mountain front. Contrasting the adjacent relatively arid plateau, the La Platas and the intervening rugged hill region between the La Plata and the San Juan mountains are well watered and well timbered. Several peaks in the La Plata exceed 3,660 $\mathrm{m}$. The north side of the La Plata Mountains drain into the Dolores River, and the remaining sides flow into the San Juan River (Figure 2).

Although climatic data are not avaflable or the La Plata Mountains specifically, Bradiey and Barry (1973) found that precipitation records from stations throughout southwestern Colorado were highly correlated. Climate records (Table 1) illustrate increased precipitation and reduced temperature with elevation. Barry and Bradley (1976) indicate a sumer lapse rate for the San Juan National Forest in southwest Colorado of $-0.82^{\circ} \mathrm{C} / 100 \mathrm{~m}$ and an annual lapse rate of $-0.59^{\circ} \mathrm{C} / 100 \mathrm{~m}$, while Betancourt (1984) reports a slightly lower annual figure for southeastern Utah $\left(-45^{\circ} \mathrm{C} / 100 \mathrm{~m}\right)$.

The precipitation distribution through the year in the Four corners region is bimodal (Figure 2), with pronounced cool and warm season maxima, the latter of which has been recognized as a monsoon (Bryson and Lowry, 1955; Huntington, 1914). The monsoon precipitation in the Four Corners region results primarily from moisture sweeping from the south (Figure 4). South and southeast of the monsoon boundary (and mostly at higher elevations where the growing season is still adequate), the modern dry farmers ralse sumer crops such as corn, beans, and potatoes. North and west of that monsoon boundary at 
higher elevation, the soll molsture obtained from winter prectpitation is usually adequate to allow dry farmers to ralse winter and spring wheat. However, by midsumer soll moisture must be supplemented with irrigation to allow the summer crops to mature.

The climatic differences in the 2,300 of elevational change between the San Juan River and the highest La Plata Mountain peaks provide several vegetation zones. Flgure reconstructs the native vegetation circa 1920, which was just before the extensive use of the tractor. The vegetation reconstruction is based on old photographs, historic descriptions, maps, and fossil pollen evidence (Petersen et al., 1985; Petersen et al., 1987).

The extensive stands of sagebrush (Arteaisia $t$. identata) that occur to the west of the La Plata Mountains led Newberry (1876:84) to name the divide between the San Juan and Dolores rivers (extending from Mesa Verde west to Comb Ridge, near Blanding, Utah) the "Sage Plain." This sagebrush-covered plateau $\left(10,360 \mathrm{~km}^{2}\right)$ ranges between 1,500 and 2,100 melevation (Gregory and Thorpe, 1938). Much of the area today between 2,010 $\mathrm{m}$ and 2,380 $\mathrm{m}$ elevation has been cleared of natural vegetation and is under dry-land cultivation. In Figure 5 that zone (or elevational belt) of cultivation represents primarily the higher elevations of the pinyon and juniper, most of the big sagebrush, and the lower elevational linit of the montane scrub mapping units. This relatively narrow agricultural belt is farmable because of the good solls and because it is both wet enough (greater than $35.5 \mathrm{~cm}$ of annual precipitation-of which $10 \mathrm{~cm}$ fall during the warm season) and warm enough (including a greater-than-110-day frost-free season) to allow routine dry farming of such crops 2: corn, beans, potatoes, and grains (Petersen et al., 1987; U.S. Departmant of Agriculture, Soll Conservation Service, 1976).

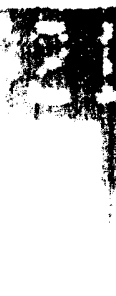


WHC-SA-1382-FP

When farming within this belt, contemporary farmers often discover the cultural remains of ancient Anasaz1, who farmed corn, beans, and squash on the same land hundreds of years earller. The flanks of the La Plata Mountains in southwestern Colorato are surrounded by vast areas containing evidence of Anasazi occupation, the most famous being preserved in the boundartes of the Mesa Verde National Park (Osborne, 1965; Mormington, 1947). Because modern changes in either moisture or summer warmth could affect the width or elevational range of the present potential dry-farming belt, this wust also have been true for the Anasazi.

\section{Research Stratogy}

In this study the prehistoric elevation and width of the dry farming belt is reconstructed and contrasted with that of the present, based on the premise that knowledge of the history of that belt would be useful in unvelling the history of Anasazi settlement and movement. This is because the climatic factors that affect horticulture (1.e., sufficient growing season and notsture for dry farming) are generally the same factors affecting the natural plant community distribution and composition. The index used for hypothesizing the width of the dry-farming belt is the changing width and elevation of the spruce (Picea engelmannif) forest zone in the La Plata Mountains. This index was obtained by analyzing pollen records from two different elevations within the spruce zone. The lower-elevation record provided a history of the molsture-dependent lower-elevation spruce boundary while the upper-elevation record provided a history of the temperature-dependent timberline. Because spruce growth responds differently to climate variations at different. 
WHC-SA-1382-FP

elevations, the combined radlocarbon-dated pollen records from the two sites yield climate information not obtainable from elther site alone. In addition. the changing record of pinyon pine (Pinus edulis) pollen, which wafted up from the surrounding lowlands and was deposited at the lower pollen site, is used as a measure of the changing number of pinyon trees on the landscape. A third pollen site that occurs within the potential dry-farm belt was used to verify some of the rei:onstructions obtained from the pollen records in the spruce forest. Some of the more important findings are sumarized here; additional detall is reported elsewhere (Petersen et al., 1985; Petersen et al., 1987; Petersen, 1988a).

\section{Results and D1scussion}

Location of Pollen Sites and the Spruce Forest Zone. Twin Lakes and Beef Pasture are located on the west slope of the La Plata Mountains, $45 \mathrm{~km}$ east of Corte?, Colorado, near the drainage divide between the Dolores and San Juan rivers (Figure 5). Twin Lakes (3290 m; NEI/4 SE1/4 NE1/4, sec. 18, T37N, R1IW, La Plata, Colorado, 7.5 minute quadrangle) is $250 \mathrm{~m}$ below timberline in a depression near the headward snout of a landslide (Petersen and Mehringer 1976). Twin Lakes and the adjacent sedge meadow are surrounded by an open Engelmann spruce and subalpine fir (Ables laslocarpa) forest that has been logged recently.

Beef Pasture (3,060 m; S1/2 SHI/4, sec. 11, T37W, R12W, Rampart Hills, Colorado, 7.5 minute quadrangle) is an open 75-ha grass and sedge madow surrounded by a mixed-conifer forest at the lower limit of the dense 
sprurs-fir forest. The surrounding trees are spruce, Douglas-fir (Pseudotsuga menziesil), and aspen (Populus treauloldes).

Confirmation of some aspects of the La Plata Mountain paleoenvironmental reconstruction are provided by a third pollen site, Sagehen Marsh (2,085 $\mathrm{m}$; SHI/4 NE14; $\sec 36$, T38H, R16H. Trimble Point, Colorado, 7.5 minute quadrangle). located in the Dolores Project ares in a valley that drains into the Dolores River (Petersen et al., 1985; Petersen, 1985). Sagehen Marsh was dammed by an alluvial fan and surrounded by a mosatc of sagebrush, pinyon (Pinus edulis), Juniper (Juniperus osteosperma and Juniperus scopulorum) and oak (Quercus ganbelii) before being submersed in the McPhee Reservoir.

The stippled area in Figure 6 indicates the zoris of relatively derses spruce around Twin Lakes in the La Plata Mountains. Results of surface polion studies and documented historic changes indicate that the large, heavy spruce pollen does not travel very far from the source tree (King, 1967; Maher, 1963; Wright, 1952) and so is a good indicator of the proximity of the trees. The location of the two pollen sites make them especially sensitive to the changes in the width of the spruce forest. A depression of upper timberline of only 100 would decrease the area occupled by forest nearly $25 \mathrm{~km}^{2}$, doubling the area above timberline. Actualiy, the pollen record at Twin Lakes does respond to changes in elevation of upper timberline, especially to timberline receding to lower elevations. Beef Pasture's location (at the current lower elevational limit of dense spruce forest) makes it particularly sensitive to the elevational changes in that boundary.

Dating and Pollen zones. Age determination of vegetation change in the La Plata Mountains is alded by 17 radiocarbon dates (Figure 7). Because 
WHC-SA-1382-FP

Bepf Pasture accumulated almost twice as mush sediment over the last 5,600 yr, the depth scales in Figure 7 have been adjusted to allow clear comparison with Twin Lakes. The lines between samples are approximations based on visual judgement. This approach (instead of using a IInear regression) was used because of the apparent correspondence in the depositional histortes between the two sites. The sedieants from both sites are primarlly peats that have been shown, in some environaents, to have varying rates of deposition depending on the prevalifing climate. Slower accumulation rates usually occur during period of shorter, culder, drier sumers, while faster rates occur during longer, warmer, wetter sumers (Malaurie et al., 1972:116; Nichols, 1975:60-70; Short and Nichols, 1977:288). Examinstion of the deposition rate curves for both Twin Lakes and Beef Pasture between 5,000 and 2,500 $\mathrm{gr}$ B.P. show marked similarities. For instance, the deposition rate between 3,000 and 2,500 yr B.P. increased at each site, and the comparable age estimates for the zone $3 / 4$ boundary (approximately 3,400 yr B.P.) and the zone $4 / 5$ boundary (approximately 2,700 yr B.P.) are relatively tightly constrained by radiocarbon dates.

A computer clustering program was used to segregate adjacent pollen samples from each of the two sites into similar groups based on the assumption that a climate change long and severe enough to affect vegetation in the La Plata Mountains would be recognizably reflected at both sites (Petersen, 1988a). Like samples from each site were grouped into a number of pollen cones, and the zones were numbered from botton to top (Figure 7). Zone boundaries for each site were drawn to fall precisely on a single pollen sample so that the correlation of zone boundaries between the two pollen sites would be unambiguous. The radiocarbon age of the sample falling on the zone 
WHC-SA-1382-FP

boundary was estimated as shown in Figure 7. Zone boundaries important to this study include those for zones $4 / 5,5 / 6$, and $6 / 7$.

To facilitate correlation between dated regional Anasazi archeological sites and the La Plata Mountain pollen sequence the pollen sample ages wera converted from the estimated radiocarbon ages derived from flgure 7 to treering calibrated calendar dates. That conversion is discussed in more detall in the following sections.

Pollen Ratios and Their Mistoric Climatic Calibration. The interpretation of vegetation change presented here relles heavily on speciftc pollen ratios from Twin Lakes and Beef Pastures. At Beef Pasture, near tine lower spruce-forest border, the spruce to pine pollen-ratio curve was selected as the best record of the movement of the lower limit of the spruce forest (Figure 8). The ratio value is plotted on a negative $y$-axis that starts at zero and increases. This visually displays the relative elevational changes in the lower spruce border. Increases in the spruce/pine ratio are plotted farther from the origin and represent, relatively, a lowered elevation limit for the lower spruce zone boundary.

Repeat photographs in the La Plata Mountains and surrounding regions document historic expansion to lower elevations and the thickening of the lower spruce forest border over the last $100 \mathrm{yr}$ (Petersen, 1988a). This expansion corresponds to a conconitant increase in effective moisture primarily in the form of increased winter snow pack (Dix and Richards, 1976); spruce is relatively shallow rooted and cannot tolerate much soil drought (Daubenmire, 1943; Pearson, 1931). 
Ai Twin Lakes, the proportion of conifer pollen (spruce + fir + pine) to pollen from nonarboreal plants (NAP) is selected to represent the relative fluctuations of the timberline (Figure 8). This ratto, rather than that used at Beef Pasture, was chosen because the Twin Lakes area recently was logged, thus artifictally removing some spruce trees and affecting the modern Twin Lakes spruce-to-pine ratio. The ratio of all conifers to MAP was used to offset the effect of modern logging.

Repeat photographs document that the tree-line in the La Plata Mountains has risen about 50 to $100 \mathrm{~m}$ in the last $100 \mathrm{yr}$, and there has been a concomitant change in tree-growth form at the tree-line where kruwimolz form has changed to non-krumaholz growth forw. Rinys from trees at timberline have changed from narrow to wide, coinciding with the extension of the growing season at the lower elevation during part of the same time pertod (Petersen, 1988a). Because the major limiting climatic factor for tree growth near timberline is sumer temperature (Daubenmire, 1954; Tranquillini, 1979; Wardle, 1974), these changes indicate an increase in summer temperature from last century to this century.

The present high polien ratios at the modern surface of Twin Lakes and Beef Pasture (Figure 8) may be exaggerated. Thousands of hectares of sagebrush and pinyon pine were cleared by modern farmers in the region after 1920 (Petersen et al., 1987). Because these plants are wind pollinated, their pollen is widely distributed beyond the source plants. Extensive removal (such as the clearance by farmers) of these pollen sources would tend to decrease their proportion in the pollen rain deposited in the spruce forest and probably would enhance the relative proportion of spruce polien deposited. The historic expansion at both the upper and lower 1 init of the spruce forest 
WHC -SA-1382-FP

in the 1. Plata Mountains is documented, but the magnitude of that expansion as reflecied in the modern surface pollen rattos at Twin Lakes and Beef Pasture (Figure 8) probably is exaggerated because of the blas introduced by the lowland clearing. The unblased ratto should be below that of the modern but higher than the mean Iines shown in Figure 8.

Correlation and Dating of Twin Lakes and Beef Pasture Records. The age assignment given to each of the pollen samples in figure 8 depends on many critical assumptions. One of these is that pollen zone boundaries can be correlated between the two sites. Zone 4/5 boundary (at the left edge of Figure 8) was assigned using radiocarbon dating, the results of the pollen sample clustering computer program, and the pollen ratio signature just to the right that indicates a relatively short period of time, characterized by a very narrow spruce forest. Because the recovery of the forest seems to be as rapid as the onset, the trees located near the climatically stressed upper and lower margin of the spruce forest zone simply may have curtailed pollen production temporarily, recovering when conditions improved (Hevly, 1981; Nichols, 1975:28-29) rather than reflecting only the loss of trees, which were later replaced by seedlings that grew to mature pollen producing trees. Another such narrow forest episode, along with the computer pollen clustering results, was used to correlate the samples on the zone 5/6 boundary. Finally, the correlation for zone $6 / 7$ boundary was accomplished by aligning the samples showing the broadest spruce forest zone down core from the present.

None of these chree anchor points have radiocarbon dates that coincide directly with them, but each has a date closely associated with it. 
WHC-SA-1382-FP

Initially, the tables of Damon et al. (1974) were used to convert the radiocarbon age of the radiocarbon sample to a tree-ring corrected calendar age. Because the bracketing range of the standard deviation on the radiocarbon dates (Table 2) is in excess of $100 \mathrm{yr}$, the calendar dates for the zone boundaries were not assigned in increments of less than a half century. The radiocarbon dates from both Twin Lakes and Beef Pasture were use to constrain the earliest narrow spruce zone eplsode shown on the extrem left of Figure 8 ; it was assigned an age of 800 B.C. The zone $4 / 5$ boundary that falls on the left edge of the figure was assigned a calendar age of 900 B.C.; A.D. 550 was assigned to the zone $4 / 6$ boundary; and A.D. 1100 was assigned to the widest spruce forest of zone 6 at the zone $6 / 7$ houndary.

Once the calendar ages were assigned to the zone boundaries, the deposition curves based on those in figure 7 were used to assign appropriate calendar ages to every sample. These ages then were used to plot the pollen ratios and pinyon pine values in Figure 8 . When Stuiver and Reimer (1986) became available, the conversions to tree-ring corrected calendar dates (Table 2) were compared; the data comparison indicated that the zone 6 boundaries could be shifted slightly. However, based on the results of treering correlation (which is discussed in the following sections), the original dates were retained.

Correlation and Relative Calibration of the La Plata Mountain Pollen Ratio Record with Treo-Ring Indices. A model of the relationship between tree growth and climate has been devised by fritts (1976) that shows that stored food reserves are the link between the previous year's climate and current year's growth. That is, the food reserves (and its manifestation in a 
resultant tree-ring width) are constrained in trees growing at low elevations by moisture, whereas at high elevation, reserves are constrained primarily by summer temperature. In the latter case, the summer must be long enough or warm enough to allow production of adequate foud reserves to be used for respiration and needle replacement requirements. In addition, the reserves must be suffictent for ring production the following year; the larger surplus values correlate to wider rings, so the wamer sumers lead to wider rings. LaMarche and Stockton (1974) obtained ring width records for highelevation bristlecone pine (Pinus aristata) from Almagre Mountain (near Pikes Peak, Colorado). The Almagre record was selected for this study because it was the longest regional recurd that could be us. I to reconstruct sumer warmth. The published yearly indices (Drew, 1974) were used to obtain averages of successive 20-yr means, which are plotted in Figure 8 on the 11 th year. Changes in these tree-ring indices reflect long-tarm changes in summer temperature. A decrease in the indices indicates a lower relative summer temperature (or, for the purposes of this report, a shorter growing season). Points of correlation between the Almagre and Twin Lakes records are shown by arrows in Figure 8.

In addition to the record from Almagre Mountain, many high-elevation bristlecone pine records for the western United States show very narrow rings for the mid-1800s (LaMarche and Stockton, 1974), coinciding with an intense cold period documented by deposition of Little Ice Age glactal moraine in the mountains of the western United States (Porter, 1986). Tree rings of timberline spruce trees in the La Plata Mountains also show very narrow rings for the mid-1800s (Petersen, 1988a). Scuderi (1990) reports narrow tree rings 
recorded for high-elevation fox tall pine (pinus balfouriana) in the sterra Nevadas of California for the mid-1800s, which he correlates to sinflarly aged lichen-dated glactal moraines.

As evident from Figure 8 , the spruce forest in the La Platas was relatively narrow in the mid-1800s. According to Lamarche (1974), the treering widths from bristlecone pines (in the White Mountains of eastern California), located near their upper and lower elevational ranges, ire indicative of conditions that were relatively cold (based on narrow rings in high-elevation trees) and dry (based on narrow rings in low-elevation trees), compared to current conditlons.

As discussed previously, pollen zone 6 begins .. Twin Lakes with a very low ratio of conifer/NAP in A.D. 500s. Additional corroborative evidence for a widely spread cold episode during the 6th century is provided by Scudert (1990), who reports narrow tree rings at that time in high-elevation fox tall pine records (for the Sierra Nevadas), which he correlates with simtlarly aged lichen-dated glacial moraines.

An Index of Pinyon Pine, a Proxy for the Sunar Monsoon. The bottom panel of Figure 8 plots the number of pinyon pine pollen grains falling on a $1 \mathrm{~cm}^{2}$ of surface area during 1 yr at Beef Pasture. These figures were calculated using the deposition rate curve based on figure 7 to estimate the rate (cm/yr) applicable for each sample. This was obtained by calculating the slope of the tangent at the point where the sample depth intersects the deposition curve. This figure $(\mathrm{cm} / \mathrm{yr})$ was then multiplied by the pinyon pine pollen content from each sample (grains $/ \mathrm{cm}^{3}$ ) as estimated by using the Lycopodium spore tricers 
intruifuced for that purpose. This gave a yearly pinyon pine pollen influx value of pollen grains per square centimeter per year (grains $/ \mathrm{cm}^{2} / \mathrm{yr}$ ).

Changes in pinyon pine pollen absolute influx values are evident for the past $200 \mathrm{yr}$; Figure 8 indicates an increase followed by a decrease. This reflects the actual history of pinyon pine trees on the landscape. Beginning In the last century. pinyon pine has been expanding its range in the four Corners region (Erdman 1970:21; Spencer 1964:148; Van Pelt, 1978). That trend probably would have continued in the Great Sage Plain, except for the extensive clearing for farming. A 20-fold increase (from 105 to $1,988 \mathrm{grains} / \mathrm{cm}^{2} / \mathrm{yr}$ ) in pinyon pine pollen accumulation is evident at Beef Pasture for samples dated between A.D. 1750 and 1:J0. After 1890, pinyon pine pollen influx decreased steadily at Beef Pasture to $458 \mathrm{grains} / \mathrm{cm}^{2} / \mathrm{yr}$ (a 4-fold decrease) in a sample dating to 1970. The record at Sagehen Marsh has even tighter chronological control and clearly records the same pattern (Petersen, 1985; Petersen et al., 1987).

Summer rainfall seems critical for pinyon seedling establishment and tree growth. Physiological adaptations such as root characteristics, large seed, needle form and number, cuticle thickness, and small growth form all seem to be special adaptations that take advantage of summer precipitation (Daubenmire 1943:11; Emerson 1932; Wells 1979:318). In addition, there is a coincidence between the geographical distribution of sumer rainfall in the west and that of pinyon pine. Arguments are presented el sewhere (Petersen, 1985; Petersen, 1988a) to substantiate pinyon pine as a good index for longterm changes in the relative strength of the summer monsoon and Davis (this volume) provides some corroborative evidence for that conclusion. When the monsoon is weak, it arrives later, does not penetrate as far to the northwest 
WHC-SA-1382-FP

(figure 4), and leaves earlier. When it is strong. Just the opposite is true. figure 8 indicates that during the last 2,800 yr there have been eplsodes of the monsoon beins weaker than the present, and between A.D. 750 and 1150 it was at least as strong as the historic period.

Cor.elation with Other Records. Schoenwetter (1966) was the first to propose a chronology of fluctuating winter-dominant precipitation during Anasazi occupation of the Four Corrier reglion. He also suggested that the times of low winter precipitation probabiy were offset by increases of summer precipitation. His independently dated climatic sequence for effective moisture (Schoenwetter, 1966, 1967, 1970; Schoenwetter and Eddy, 1964), and those of Euler et al. (1979) and Dean et al. (1985) closely match the tining and fluctuations presented here.

Another independently dated test of the Beef Pasture reconstruction is provided by the tallying of the plth dates of ponderosa pine (Pinus ponderosa) timbers that were used in construction by the Anasazi in the Dolores Project area. Dates of ponderosa pine seedlings establishment coincide with springs characterized by higher-than-average precipitation, whereas low spring precipitation or snowpack inhibit establishment (Schubert, 1974). The cluster of Dolores pith dates prior to A.D. 900 matches the periods reconstructed to be at least as wet at the present (a ratio value greater than 0.60 in Figure 8) (Petersen, 1988a). Additionally, the direction of vegetation change indicated by paired pollen samples of differing age from well-dated superimposed archaeological floors in the Dolores Project (Petersen, 1986) is in agreement with that proposed here for the time shared periods. 
Birds Eyo View of the Changing Width of the Potential Dry. Farming Belt. The Dolores Project Area is situated near the upper modern limits of the dryfarming belt; this belt, defined by both molsture and temperature, exists within narrow latitudinal limits (Figure 9a). Consequently, prehistoric agricultural activity should have been affected by changes in the elevational extent (width) of the agricultural belt as modern dry farming is today. The reconstruction presented in Figure 9 and 10 are based on an interpretation of the climate indices in Figure 8 . The combination of Colorado Front Range tree-ring width data with the Twin Lakes conifers/NAP pollen ratio is used to locate the upper elevational limit of the dry-farm belt and described in terms of growing season length. The Beef Pasture spruce/p ne ratios are used locate the lower elevational extent of the dry-farming belt (supplemented with archaeological site distribution data as discussed below) and described in terms of jet-stream derived winter precipitation. Finally, pinyon pine pollen influx is used to evaluate the risk for dry farming within the farm belt and also is used to characterize the strength of the summer monsoon. The pattern shown in Figure 9a is the historic pattern and represents the reconstruction for the period A.D. 600-800.

At the beginning of the A.D. 600-800 period, after the very narrow spruce zone centered about A.D. 550, the Almagre tree-rings show a very rapid increase in width. At that time the Anasazi began appearing in large numbers in southwest Colorado (Schlanger, 1988), which coincides with the region emerging from the grips of cold weather of the 6th century. The rapid warming widened the dry-farming belt to about the same size it is today. The pollen samples dating to the mid A.D. 600s from Sagehen Marsh (Table 2) in the Dolores Project area are indistinguishable from the pollen samples that date 
WHC-SA-1382-FP

shurtl, before the 1920 clearing (Petersen 1984, 1988b; Petersen et al.. 1987). During this perlod populations grew and the Anasazt thrived.

About A.D. 750, long-term winter drought moved Into the area and the agricultural zone narrowed by about half of that today (f g gure 9b). That winter drought continued for about $200 \mathrm{yr}$; however, it was offset somowhat by increased summer convective storms that more commonly discharged preclous moisture near the elevation of the potential dry-farm belt, rather than at lower elevations (Farmer and Fletcher, 1971; Petersen et al.. 1987). The large population increases that occurred in the Dolores Project area at that time cannot be accounted for by births alone, suggesting that the Anasazi survived by moving their fields to higher levations and explotting the narrowed (but still productive) farm-belt (Schlanger, 1988). Historic documents show that about half the farm land in the region was abandoned during the severe drought of the 1930s, providing an analog for a narrowed dry-farm belt (Gregory and Thorpe, 1938; Petersen et al., 1987).

There is a pertod of narrow tree-ring widths in the Almagre record that dates to the 10th century. A further test of the correlation between narrow tree-rings and sumer warmth or growing season length is provided by Dolores Project archaeological data. Areas subject to cold air pooling were mapped in the Dolores Project area, and it was found that although these areas had been almost continuously occupled since the 7 th century, they were suddenly abandoned by Anasazi farmers for a short time in the loth century when the Almagre tree-ring record suggests cooling. The farm land was again reoccupied in the 11 th century when tree-ring width at timberline again became wider (Breternitz et al.. 1986; Petersen et al., 1987). 
WHC-SA-1382-FP

By A.D. 1000, the climate had warmed to a point that growing season was dequate for farming in the Dolores Project area, and the summer monsoons moisture was supplemented by a large increase in the amount of winter precipitation. This combination greatly expanded the farming belt, dropping its lower 1 imit to about $1,600 \mathrm{~m}$ elevation (Figure 10a), which more than doubled the amount of farmland avallable, compared to that of today (as shown in Figure 9a). During this time period, there was a tremendous explosion in archeological evidence (locally called the PII expansion) for areas currently below the modern extent of the farm belt.

It is generally accepted that Anasazi dwellings would not be located too far from their corn fields. For Instance at Hovenweep National Monument $(1,600 \mathrm{~m})$, where there are abundant Anasazi ruins, one cannot grow corn today because the $30 \mathrm{~cm}$ of annual precipitation at that elevation is not adequate. In fact, modern farmers cannot obtain crop insurance for dry farming for elevations below $1,830 \mathrm{~m}$ (some $230 \mathrm{~m}$ higher in elevation) and routine dry farming is not practice below 2,010 m (Petersen et al., 1987). However, Woosley (1977) found in surface pollen transect on suspected Anasazi dryfarming fields at Hovenweep that there was corn and bean pollen still preserved in the soil by the arid climate. Corn pollen is a relatively large pollen grain that usually does not travel more than a few meters from the source plant and even in modern corn fields is only 1 or 2 percent of the pollen count (Martin, 1963:50). To find it in such upland field locations suggests that conditions for rainfall farming had to have been drastically different from current conditions. Possibly the combination of the high winter snowpack like the early part of pollen zone 6 (Figure 8) but with added component of additional sumer precipitation combined to produce the 


\section{WHC-SA-1382-FP}

unoruerdented broad farm belt. It was as if there was greater vigor in the generdl circulation regime whereby more oceanic climate (both summer and winter) were pulled deeper inland (see Wallen [1955) for a possible explanation for such an occurrence earlier this century).

The period from A.D. 1000 to A.D. 1100 actually coincided with the zenith of the Anasazi cultures. Populations increased dramatically in the Four Corners region and elsewhere (Figure 1) and developed complex social, economic, and political structures, the most famous of which is preserved in Chaco Canyon National Monument in northeastern New Mexico. The monsoon boundary (Figure 2) most likely was located north of its present location.

Interestingly the expansion of the farm beit at its lower elevational limit in the four Corners region actually lead to a decrease in population in the Dolores Project area (Schlanger, 1988), now located at the uppermost margin. This was most likely because the Anasazi farmers now had a greater choice of land and could avoid the cold air drainage that often occurs in the Dolores River valley proper (Petersen et al., 1987).

Soon after A.D. 1100, another winter drought began to move into the region, narrowing the potential dry-farm belt from the botton (Figure 9a). As before, the Anasazi began to adjust, but unlike the drought of the A.O. 800 s (Figure 8), summer rain was not as plentiful or dependable, the summer monsoon boundary was most likely located south of its present locations. Summer rains arrived later, left earlier, and were not as predictable. This time the Anasazi compensated by utflizing a number of water control strategies such as check dams, ditches, and reservoirs (e.g., Erdman et al., 1969).

Then severe, dry cold started to move into the region about A.D. 1200, making farming risky at higher elevations (Figure 8). As the summer and 
WHC-SA-1382-FP

winter is roughtit pinched the farming belt from the bottom, cold pinched it from the top. By A.O. 1200 the Anasazi began leaving the area. The most severe impact of the combination was felt late in the A.D. 1200s, where in effect, the farming belt was squeezed to the point that it disappeared (Figure 10b). The Anasazi stmply left the higher elevations of the Four Corners region and headed south, seeking more dependable summer monsoons, sufficient winter precipitation (or areas that could be irrigated), and longer growing seasons (Figure 1).

Interestingly, the cold, dry conditions that began in the A.D. 1200s lasted for hundreds of years -- without much change -- to about the A.D. 1850s. Because weather stations in the region were mostly established after 1895, somewhat after the change to warmer and wetter conditions that have existed during the last 130 years or so, our modern weather reciords give little hint of the severity of conditions that had occurred. The climatic conditions during that period is suggested iy an accounted for by a military expedition led by Col. Macomb into the region in 1859. Newberry (1876:76-77, 88-89) observed a broad surface of snow covering the San Miguel Mountains of the San Juans in early August (today it is gone by early July), and from a site near modern day Yellow Jacket they observed that it was too high, too coid and too dry to grow corn and other crops in the area. This same locality today supports thousands of hectares of successful dry farming of those very same crops (Petersen et al., 1987; Petersen 1988a).

In the 1870's, some 20 to $30 \mathrm{yr}$ after Macomb's and Newberry's expedition, when white settlers began moving into the area (Figure 9a), the mountain peaks were clear of snow in late summer, young pinyon trees were invading the sagebrush, and the spruce forest was beginning to expand. All 
WhiC-SA-1382-FP

these were signs that the farming belt had rebounded and that the new settlers would find ideal dry-farming conditions with abundant sumer and winter precipitation and an adequate growing season. The climate had reverted to conditions similar to those during the 700-yr Anasazi occupation, and the modern farms could locate exactly where the Anasazt had farms during their sojourn in the region.

\section{Conclustons}

In the next century, increases in atmospheric trace gas concentration could warm the global average temperature beyons what it has ranged during the past century. Examination of larger-than-historic climatic changes that have occurred in the past in specific regions provides realistic context for evaluating such potential future changes. This paper has contrasted the climatic manifestation of the Little Climatic Optimum or Medieval Warm Period (AD 900-1300) with that of the Little Ice Age (AD 1300-1850) in the northern Colorado Plateau region of the southwestern U.S.A. The zenith of the Anasazi occupation coincides with the former and their dealse coincides with the latter, when conditions became too cold and especially dry (in the sumer) to support upland dry farming. During the height of the Little Climatic Optimum the region was characterized by a relatively long growing season and greater winter and sumer precipitation than that of today. This resulted in a relatively rapid development of a potential dry-farming belt that was twice as wide as the present and areas that cannot be dry farmed today were routinely farmed by the Anasazi. Such conditions would be beneficial to dry famers in the Four Corners region if those conditions were repeated in the near future. 
WHC-SA-1382-FP

Acknowledgements

Work on climatic change in the Colorado Rockies grew out of an interest fostered while I was a field assistant to James B. Benedict in the Colorado Front Range in the wid 1960s. Subsequently I studied with Peter J. Mehringer, first at the University of Utah, and later at Washington State University, and I studied with Paul S. Martin at the University of Arizona. The work reported here began in 1972 in conjunction with the Salmon Ruins Archaeological Proje. (supported in part by National Endowments for the Humanities grants R0-8637A-74-540 and RO-24580-76-630 to Cynthia Imwin-Willitam) and continued during the execution of the Dolores Archaeological rrogram (Contract No. 8-07040-S0562, David A. Breternitz senior principal investigator) funded by the Bureau of Reclamation, Upper Colorado Region, U.S. Department of Interior. Additional work has been undertaken during my employment by the Westinghouse Hanford Company, Richland, Washington (Hanford Operations and Engineering Contractor for the U.S. Department of Energy under Contract DE-AC06-87RL10930) in programs for developing defensible estimates of potential future climate for the Hanford Site and the DOE's Monticello [Utah] Remedial Action Project for uranium mill tailings. Estimates of regional climate cannot be viewed in isolation but must be viewed as part of a larger continental and global system to understand fully the underlying driving mechanisms. The views and opinions of authors expressed herein do not necessarily state or reflect those of the United States Government or any agency thereof. 
WHC-SA-1382-FP

\section{Roforences}

Barry, R. G., and Bradley, R. S.: 1976, 'Historical Climatology,' in Steinhoff, H. W., and Ives, J. D. (eds.), Ecological Inpacts of Snowpack Augmentation in the San Juan Mountains, Colorado, San Juan Ecology Project, Final Report, Colorado State University Publications, Fort Collins, pp. 43-47.

Betancourt, J. L.: 1984, 'Late Quaternary Plant Zonation and Climate in Southeastern Utah,' Great Basin Naturalist 44,1-35.

Berlin, G. L., Ambler, J. R., Hevly, R. H., and Shabes, G. G.: 1977, 'Identification of a Sinagua Agricultural Field by Aerial Thermography, Soll Chemistry, Pollen/Plant Analysis, and Archaeology,' American Antiquity $42,588-600$.

Bradley, R. S., and Barry, R. G.: 1973, 'Secular Climatic Fluctuations in Southwestern Colorado,' Monthly Weather Review 101,264-270.

Breternitz, D. A., Robinson, C. K., and Gross, G. T., (compllers): 1986, Dolores Archaeological Progran: Final Synthetic Report, U.S. Department of Interior, Bureau of Reclamation, Engineering and Research Center, Denver.

Brown, D. E. (ed.): 1982, 'Blotic Communities of the American Southwest -United States and Mexico,' Desert Plants 4(1-4),1-342. 
Bryson, R. A., and Jultan, P. R. (conveners): 1963, Proceedings of the Confr ence on the Climate of the Eleventh and Sixteenth Centuries (Aspen, Colorauo, June 16-24, 1962), NCAR Techntcal Notes 63-1, AfCRL-63-660, Nattonal Center for Atmospheric Research, Boulder, Colorado.

Bryson, R. A., and Lowry, W. P.: 1955, 'Synoptic Climatology of the Arizona Summer Precipitation Singularity,' Bulletin American Meteorological Society $36,329-339$.

Damon, P. E., Ferguson, C. W., Long, A., and Wallick, E. I.: 1974, 'Dendrochronologic Calibration of the Radiocarbon Time scale,' 39 (2 pt.1), 350-366.

Daubenmire, R. F.: 1943, 'Soll Temperature Versus Drought as a Factor Determining Lower Altitudinal Limits of Trees in the Rocky Mountains,' Botanical Gazette 105, 1-13.

Daubenmire, R. F.: 1954, 'Alpine Timberlines in the Americas and Their Interpretation,' Butler University Botanical Studies 11,119-136.

Dean, J. S., Euler, R. C., Gumerman, G. J., Plog, F., Hevly, R. H., and Karlstom, T. N. V.: 1985, 'Human Behavior, Denography, and the Paleoenvironment of the Colorado Plateaus,' American Antiquity $50,537-554$. 
WHC - SA-1382-FP

Uix, R. L., and Richards, J. L.: 1976, 'Possible Changes in Spectra Structure of the Subalpine Forest Induced by Increased Snow Pack.' In Steinhoff, H. W., and Ives, J. D. (eds.). Ecological Inpacts of Snowpack Augmentation in the San Juan Mountains, Colorado, San Juan Ecology Project, Final Report, Colorado State University Publications, Fort Collins, PD. 311-322.

Dorrah, J. H., Jr.: 1946, Certain Hydrological and Climatic Characteristics of the Southwest, Publications in Engineering No. 1, University of New Mexico, Albuquerque.

Drew, L. G. (ed.): 1974, Tree-Ring Chronologie. of Western America: IV, Colorado, Utah, Nebraska, and South Dakota, Chronology Series 1, University of Arizona Laboratory of Tree-Ring Research, Tucson.

Emerson, F. H.,: 1932, 'The Tension Zone Between the Grama Grass and Pinyon-Juniper Associations in Northeastern New Mexico,' Ecology 13,347-358.

\footnotetext{
Erdman, J. A.: 1970, 'Pinyon-Juniper Succession after Natural Fires on Residual Soils of Mesa Verde, Colorado,' Brighan Young University Science Bulletin, Biological Series 11,17-26.
}

Erdman, J. A., Douglas, C. L., and Marr, J. W.: 1969, Wetherill Mesa Studies: Environaent of Mesa Verde, Colorado, Archaeological Research No. 7B, U.S. Department of Interior, National Park Service, Washington, D.C. 
WHC - SA-1382-FP

Fuler, P., Gumerman, G. J., Karlstrom, T. N. V., Dean, J. S., and Hevly, H. R.: 1979. 'The Colorado Plateaus: Cultural Dynamics and Paleoenvironment,' science $205,1089-1101$.

Farmer, E. E., anf Fletcher, J. E.: 1971, Precipltation Characteristics of Sumer Storns at High-Elevation Stations in Utah, Forest Service Research Paper INT-110, U.S. Department of Agriculture, Forest Service, Ogden.

Fritts, H. C.: 1976, Tree Rings and Climate, Academic Press, New York.

Fritts, H. C, Smith, D. G., and Stokes, M. A.: 1965, 'The Biological Model for Paleoclimatic Interpretation of Mesa Verde Tree-Ring Series,' in Osborne, $D$. (assembler), Contributions of the Wetherlll Mesa Archaeological Project, Society of American Archaeology Memoirs 19, Salt Lake City, pp. 101-121.

Gregory, H. E., and Thorpe, M. R.: 1938, The San Juan Country: A Geographic and Geologic Reconnaissance of Southeastern Utah, Professional Paper 188, U.S. Geological Survey, U.S. Government Printing Office, Washington, D.C.

Grove, J. M.: 1988, The Little Ice Age, Methuen, London.

Gumerman, G. J. (ed.): 1988, The Anasazi in a Changing Environment, Cambridge University Press, New York. 
Heermann, 1). F., Finkner, M. D., and Hiler, E. A.: 1971, Probability of Sequences of Wet and Dry Days for Eleven Western States and Texas, Experiment Station Technical Bulletin 117, Colorado State University, Fort Collins.

Hevly, R. H.: 1981, 'Pollen Production, Transport and Preservation: Potentials and Limitations in Archaeological Palynology,' Journal of lthnobiology 1,39-54.

Houghton, J. T., Jenkins, G. J., and Ephraums, J. J. (eds.) 1990, Climate Change: The IPCC Scientific Assessment, Cambridge University Press, Cambridge, UK.

Huntington, E.: 1914, The Climatic Factor as Illustrated in Arid America, Publication 192, Carnegie Institution of Washington, Washington, D.C.

Jennings, J. D.: 1968, Prehistory of North America, McGraw-Hill, New York. King, J. E.: 1967, 'Modern Pollen Rain and Fossil Pollen in Solls in the. Sandia Mountains, New Mexico,' Papers of the Michigan Acadeny of Science, Arts and Letters $52,31-41$.

Klein, J., Lerman, J. C., Damon, P. E., and Ralph, E. K.: 1982, 'Calibration of Radiocarbon Dates: Tables Based on the Consensus Data of the Workshop on Calibrating the Radiocarbon Time Scale,' Radiocarbon 24,103-150.

LaMarche, V. C., Jr.: 1974, 'Paleoclimatic Inferences from Long Tree-Ring Records,' Science 183,1043-1048. 
I a Marche, V. C., Jr., and Stockton, C. W.: 1974, 'Chronologies from lemperature Sensitive Bristlecone Pines at Upper Treeline in the Western Untled States,' Tree-Ring Bulletin 34,21-45.

Lamb. H. H.: 1977, Clinate: Present, Past and Future, Vol. 2, Cliaste History and the Future, Methuen, London, England.

Maher, L. J., Jr.: 1963, 'Pollen Analyses of Surface Materials from the Southern San Juan Mountains, Colorado, Geological Society of America Bulletin $74,1485-1504$.

Malaurie, J., Vasari, Y., Hyvarinen, H., Delibrias, G., and Labeyrie, J.: 1972, 'Preliminary Remarks on Holocene Paleoclimates in the Regions of Thule and Inglefield Land, Above All since the Beginning of Our Own Era,' in Vasart, Y., Hyvarinen, H., and Hicks, S. (eds.), Climate Changes in Arctic Areas Ouring the Last Ten-Thousand Years: A Symposium Held at Oulanka and Kevo, 4-10 october 1971, Acta Unversitatis Ouluensis, Series A, Scientiae Refum Naturalium No. 3, Geologica No. 1, University of Oulu, Oulu, Finland, PD. 105-133.

Martin, P.S.: 1963, The Last 10,000 Years: A Fossil Pollen Record of the American Southwest, The University of Arizona Press. Tucson. 
WHC-SA-1382-FP

Martin, $;, \ldots$ and Byers, W.: 1965, 'Pollen and Archaeology at Wetherlll

Mesd, ' in Ustrorne, 0 . (assembler). Contributions of the Metherill Mesa

Archaeological Project, Soclety of American Archaeology Memolrs 19. Salt Lake

City, pp. 101-121.

Mlller, J. F., Frederick, R. H., and Tracey, R. J.: 1973,

Precipitation--Frequency Atlas of the Western Untted States, Volume

III--Colorado: NOMA Atlas 2, U.S. Department of Commerce, Mational Oceanic and

Atmospheric Idministration, National Weather Service, Sllver Springs,

Maryland.

Mitchell, V. L.: 1976, 'Regionalization of Climate in the Mestern United States,' Journal of Applied Meteorology 15,920-927.

Newberry, J. S.: 1876, 'Geological Report,' in Macomb, J. N., Report of the Exploring Expedition from Santa Fe, New Mexico, to the Junction of the Grand and Green Rivers of the Great Colorado of the West, in 1859, under the Comand of Capt. J. N. Macoub, Corps of Topographical Engineers (now Colonel of Engineers); with Geological Report by Prof. J. S. Newberry, Geologist of the Expedition, Engineer Department, U.S. Army, Government Printing Office, Washington, D.C.

Nichols, H.: 1975, Palynological and Paleoclimatic Study of the Late Quaternary Displacement of the Boreal Forest-Tundra Ecotone in Keewat in and Mackenzie, N.W.T., Canada, Occasional Paper 15, Institute of Arctic and Alpine Research, Boulder, Colorado. 
WHC-SA-1382-FP

(U.tille, O. (assembler): 1965, Contributions of the Wetherill Mesa Archacological Project. Soclety of American Archaeology Memolrs 19. Salt Lake cily

Pearson, G. A.: 1931, Forest Types in the Southwest as Determined by Climate and Soll, Technical Bulletin 247, U.S. Department of Agriculture, U.S. Government Printing Office, Washington, O.C.

Petersen, K. L.: 1984, 'Man and Environment in the Dolores River Valley, S.W. Colorado: Some Pollon Evidence,' In AMQUA 1984, Progran and Abstracts, Eighth Biennial Meeting, American Quaternary Associat in, University of Colorado, Boulder, p. 102.

Petersen, K. L.: 1985, 'Palynology in Montezuma County, Southwestern Colorado: The Local History of Pinyon Pine (Pinus edulis),' in Jacobs, B., Davis, O., and Fali, P. (eds.), Late Quaternary Palynology of the American Southest, ASSP Contribution Series, American Association of Stratigraphic Palynologists Foundation, Dallas.

Petersen, K. L.: 1986, 'Section 3: Pollen Studies: Temporal Patterns and Resource Uses,' in Petersen, K. L., Matthews, and Neusius, S. H., 'Chapter 4--Environmental Archaeology,' in Braternitz, D. A., Robinson, C. K., and Gross, G. T. (compllers), Dolores Archaeological Progran: Final Synthetic Report, U.S. Department of Interior, Bureau of Reclamation, Engineering and Research Center, Denver, PD. 184-199. 
Peturstll, K. L.: 1988a, Climate and the Dolores River Anasaz1, University of Utah Anthropological Papers No. 113, University of Utah Press, Salt Lake City.

Petersen, K. L.: 1988b, 'Comparison of Modern Surface Pollen Samples with Samples from Sagehen Marsh, Dolores River Valley, Montezuma County, Southwestern Colorado,' AMQUA 1988, Progran and Abstracts, Tenth Biennial Meeting. American Quaternary Association, University of Massachusetts, Anherst, pp. 147.

Petersen, K. L., and Mehringer, P. J., Jr.: 1976, 'Postglactal Tímberline Fluctuations, La Plata Mountains, Southwestern Col, ado, Arctic and Alpine Research 8,275-288.

Petersen, K. L., Clay, V. L., Matthews, M. H., Meuslus, S. H. (compllers), and Breternitz, D. A. (principal investigator): 1985, Dolores Archeological Program: Studies in Environmental Archaeology, U.S. Department of Interior, Bureau of Reclamation, Engineering and Research Center, Denver.

Petersen, K. L., Orcutt, J. D. (compllers), and Breternitz, D. A. (principal investigator): 1987, Dolores Archacological Progran: Supporting Studies: Settlement and Environaent, U.S. Department of Interior, Bureau of Reclamation, Engineering and Research Center, Denver.

Porter, S. C.: 1986, 'Pattern and Forcing of Northern Hemisphere Glacter Variations During the Last Millennium,' Quaternary Research 26,27-48. 
WHC-SA-1382-FP

Pyke. 6.: 1972, Some Meteorological Aspects of the Seasonal Distribution of Precipletion in the Western United States and baja Callfornia, Water Resources Center Contribution No. 139, Untversity of Callfornta, Los Angeles.

Schlanger, S. H.: 1988, 'Patterns of Population Movement and Long Torm Population Growth in Southwestern Colorado.' American Ant Iquity, 35, 773-793.

Schneider, S. H.: 1986, 'Can Modeling of the Anctent Past Verify Pradiction of Future Climates? An Editorial,' Climatic Change 8,117-119.

Schoenwetter, J.: 1966, 'A Ro-Evaluation of the N. Iajo Reservolr Pollen Chronology,' El Palacio 73,19-26.

Schoenwetter, J.: 1967, 'Pollen Survey of the Shiprock Area,' in Harris, A. H., Schoenwetter, J., and Warren, A. H., An Archacelogical Survey of the Chuska Valley Chaco Plateau, New Mexico. Part I: Natural Science Studies, Research Records 4, Museum of New Mexico, Albuquerque, Pp. 72-103.

Schoenwetter, J.: 1970, 'Archaeological Pollen Studies of the Colorado Plateau,' American Antiquity 35,35-48.

Schoenwetter, J., and Eddy, F. H.: 1964, Alluvial and Palynological Reconstruction of Environments, Navajo Reservoir District, Papers in Anthropology 13, Museum of New Mexico, Albuquerque. 
HHC-SA-1382-FP

Schubert, G. H.: 1974, Silviculture of Southwestern Ponderosa Pine: ihe status of Our Knuwledge, Forest Service Research Paper RM-123, U.S. Department of Ayriculture, Forest Service, fort Collins.

Scuder1, 1. A.: 1990, 'Tree-Ring Evidence for Climatically Effective Volcanic Eruptions.' Quaternary Research 34,67-85.

Short, S. K., and Nichols, H.: 1977, 'Holocene Pollen Diagrams from Subarctic Labrador-Ungava: Vegetational History and Climate Change,'Arctic and Alpine Research 9,265-290.

Smiley, T. L.: 1961, 'Evidences of Climatic Fluctuations in Southwestern Prehistory,' in Fairbridge, R. W. (ed.), Solar Variations, Climatic Change, and Related Geophysical Problens, Annals of the New York Academy of Sciences 95(Art. 1), New York, Pp. 697-704.

Spencer, D. A.: 1964, 'Porcupine Population Fluctuations in Past Centuries Revealed by Dendrochronology,' Journal of Applled Ecology 1,127-159.

Stuiver, M., and Reimer, P. J.: 1986, 'A Computer Program for Radiocarbon Age Callbration,' Radiocarbon 28,1022-1030.

Tranquillini, H.: 1979, Physiological Ecology of the Alpine Tieberline: Tree Existence at High Altitudes with Spectal Reference to the European Alps, Springer-Berlag, Berlin. 
WHC - SA-1382-FP

U.S. Departinent of Agriculture, Soil Conservation Service: 1976, Land Use and Natural Plant Communities, Montezuna County, Colorado, Map M7-0-23444-43, U.S. Department of Agriculture, Soll Conservation Service, Portland.

Van Pelt, N. S.: 1978, 'Woodland and Parks in Southeastern Utah,' unpublished Masters' Thesis, Departwent of Geography, University of Utah, Salt Lake City.

Hardle, P.: 1974, 'Alpine Timberlinns,' in Ives, J. D., and Barry, R. G. (eds.), Arctic and Alpine Environments, Methuen, London, PD. 371-402.

Wells, P. V.: 1979, 'An Equable Glactopluvial in the West: Pleniglacial Evidence of Increased Precipitation on the Gradient from the Great Basin to the Sonoran and Chihuahuan Deserts, ' Quaternary Research 12,311-325.

Wallen, C. C.: 1955, 'Some Characteristics of Precipitation in Mexico,' Geografiska Annaler 37,51-85.

Hoodbury, R. H.: 1961, 'Climatic Changes and Prehistoric Agriculicure in the Southwestern United States,' in Fairbridge, R. H. (ed.), Solar Variations, Climatic Change, and Related Geophysical Problems, Annals of the New York Academy of Sciences 95(Art. 1), New York, Pp. 697-704.

Woosley, A. 1.: 1977, 'Farm Field Location Through Palynology,' in Winters, J. C., Hoverweep 1976, Archaeology Report No. 3, Anthropology Department, San Jose State University, San Jose, California, PD. 133-150. 
WHC-SA-1382-FP

Wormington, H. M.: 1917, Prehistoric Indians of the Southuest, Popular Series 7, Denver Museum of Matural History, Denver.

Wright, J. H.: 1952, Pollen Oispersion of Some Forest Trees. Northeastern Forest Experiment Station Paper 46, U.S. Department of Agriculture, Forest Service, Upper Darby, Pennsylvania. 
WHC - SA-1382-FP
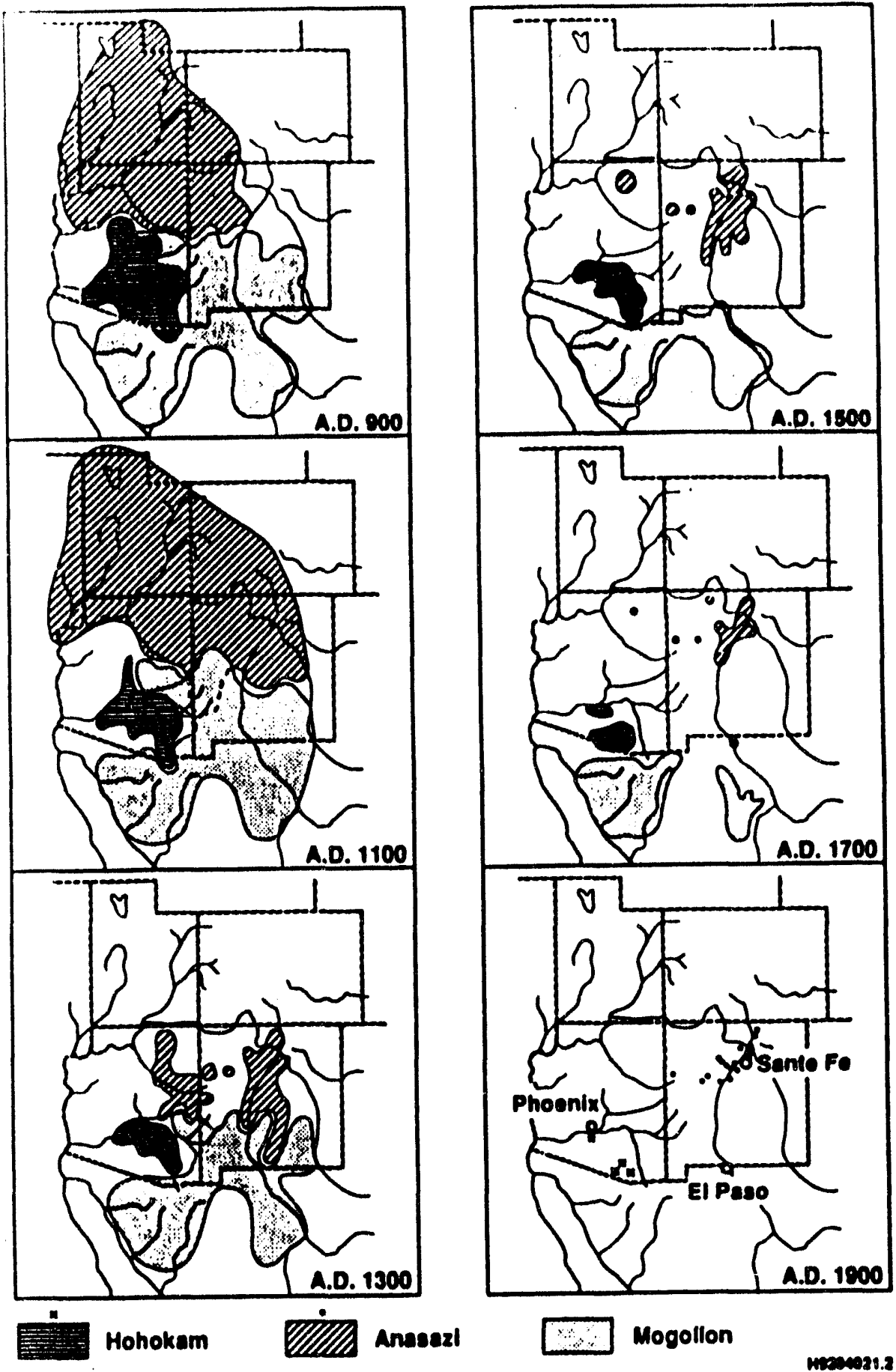

Figure 1. Map showing the approximate extent of Southwest United States Indian cultures at two-hundred-year intervals (redrawn from Jennings, 1968, Fig. 7.2). 


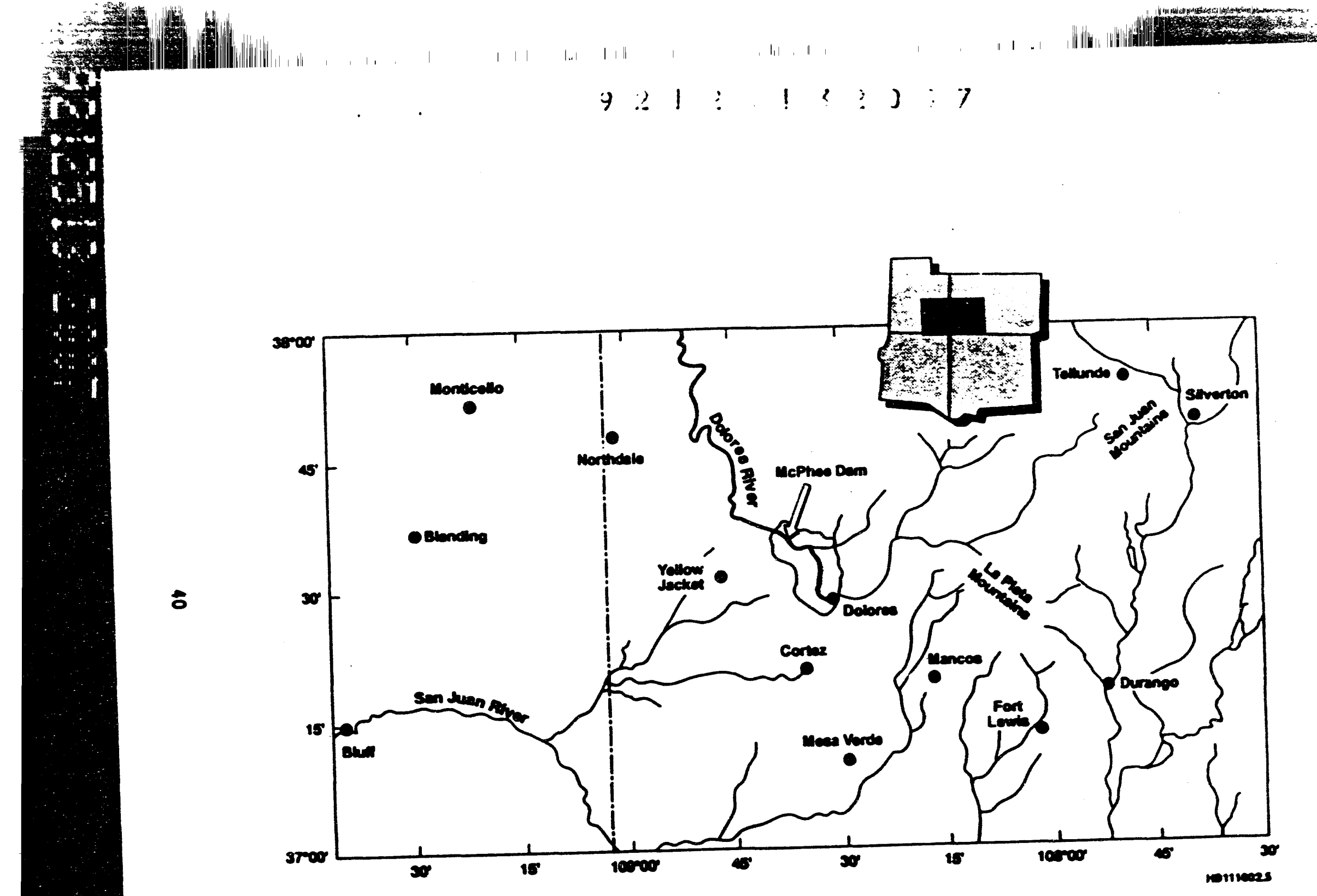

Figure 2. Map showing the location of the La Plata and San Juan mountains, the Dolores Project site (shaded) AcPhee Dan, and area weather stations in southwestern Colorado and adjacent Utah listed in Tabie 1. 
WHC-SA-1382-FP

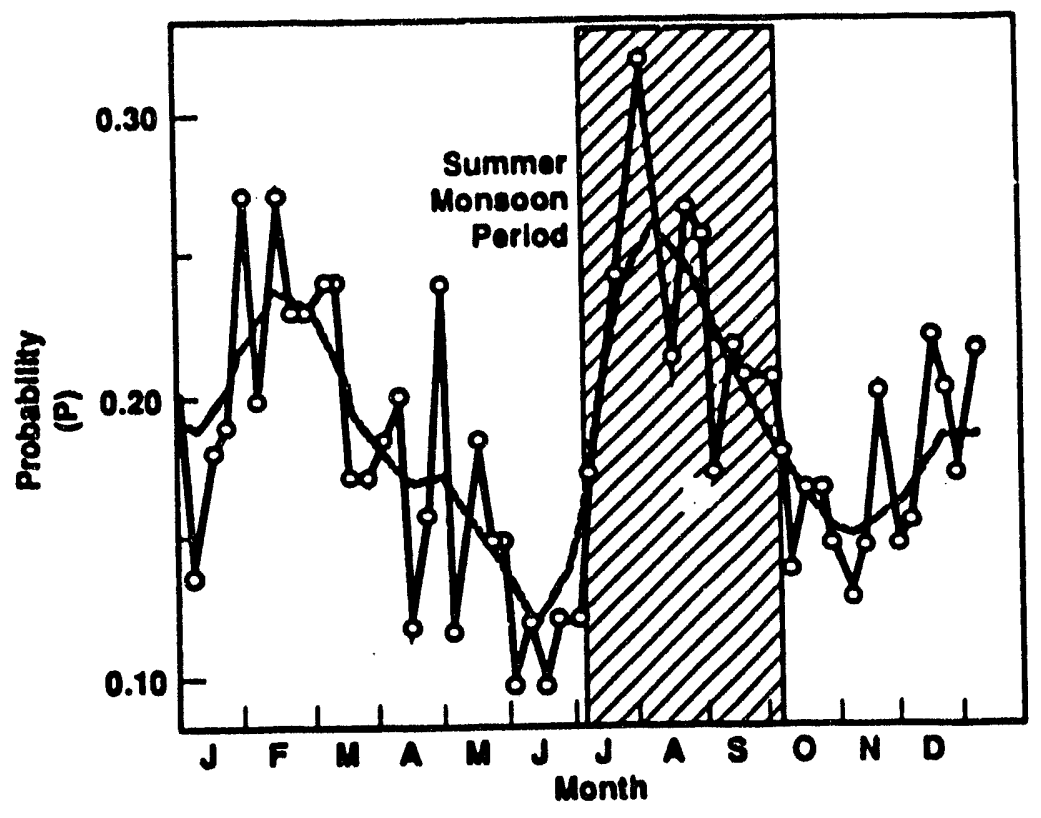

me10seres

Figure 3. Probability at Cortez, Colorado (1931-1961) that a given day of the year would be wet ( $\geq .25 \mathrm{~mm}$ precipitation). Heermann et al. (1971) computed daily average probabilities, then transformed these into weekly averages. Plots are on the midpoint of each 7-day period. Smoothing (dotted line) was done using a 9-level, weighted moving binomial running mean (e.g., $T_{0}^{\prime}=\left[1 T_{.6}\right.$ $\left.\left.+2 T_{.3}+4 T_{-2}+6 T_{.1}+8 T_{0}+6 T_{, 1} \ldots\right] / 34\right)$, and hatching shows the period defined here as the summer monsoon. 
WHC-SA-1382-FP

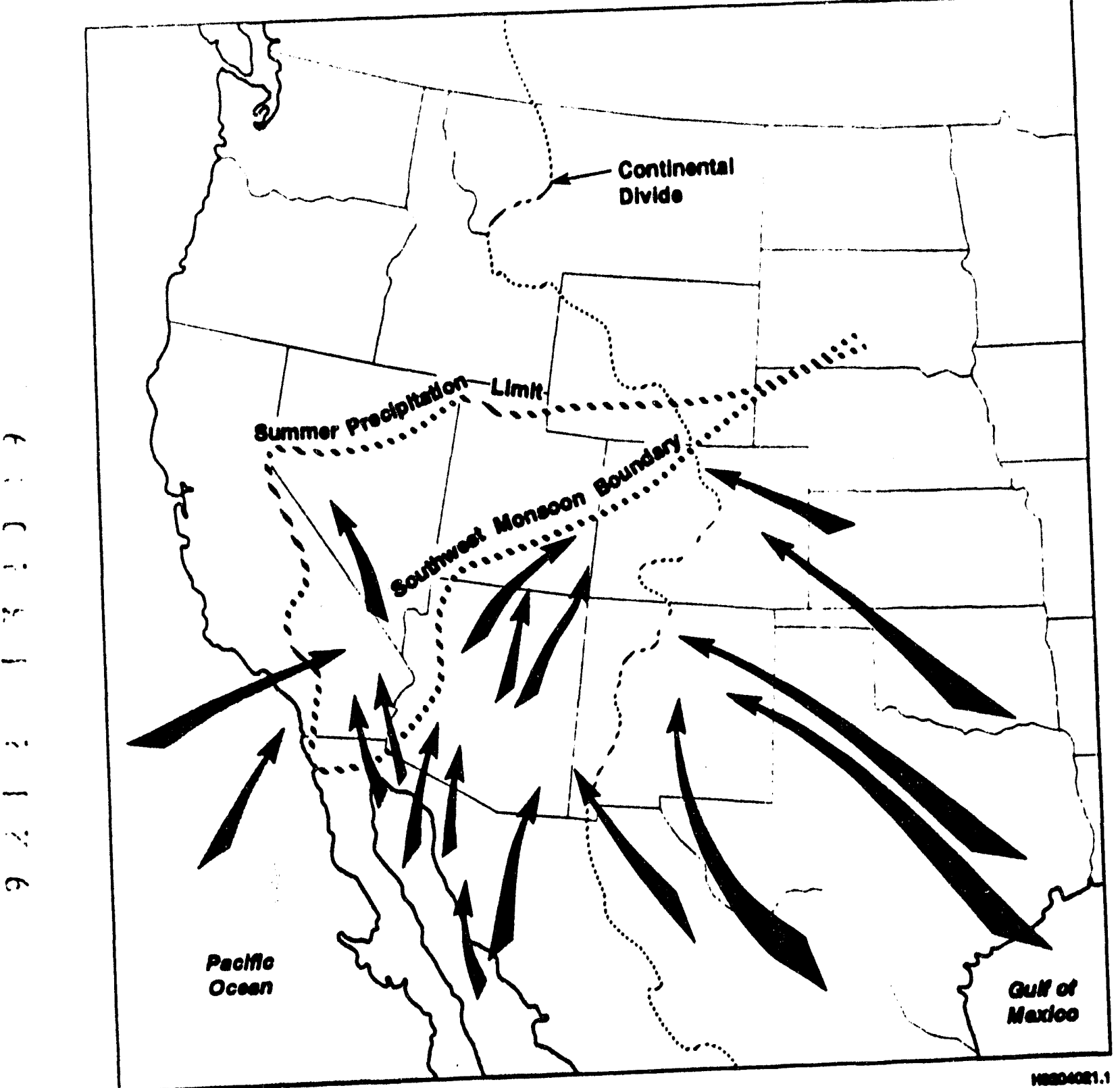

Figure 4. Climatic boundaries for the Southwest monsoon. Precipitation is Figure 4. Crith south of the southest moon boundary of Mitchell (1976), greatest east and south of the annual precipitation occurs during the warm season where more than half of the an boundary the amount of warm season

(Dorrah, 1946). North of that boundary the amount of waripitation 1 imit of precipitation decreases until it reaches the moisture in the southwest United Pyke (1972). Arrows show the main from Miller et al., 1973). 


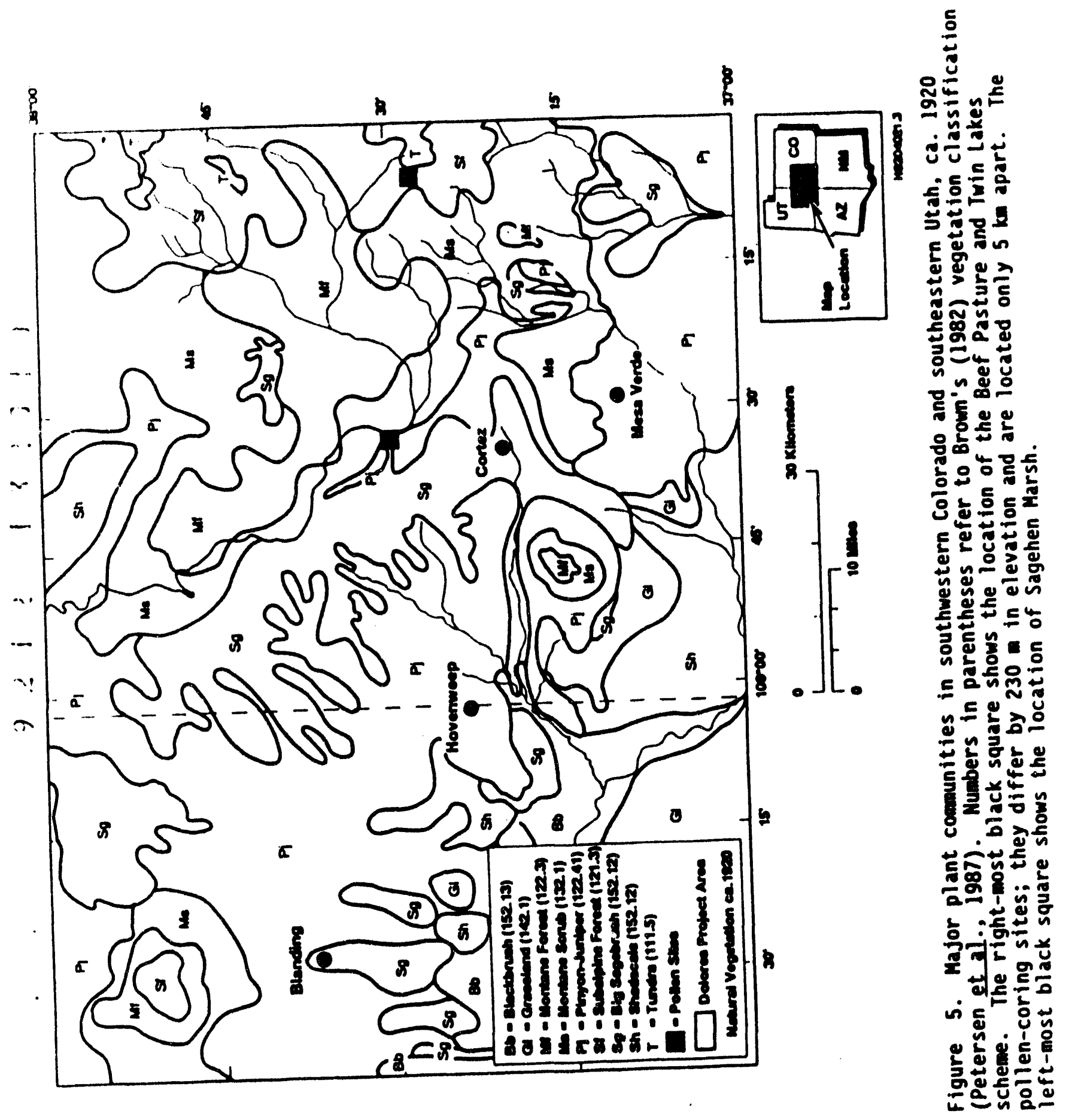




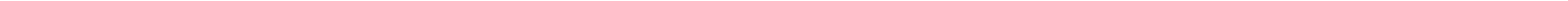




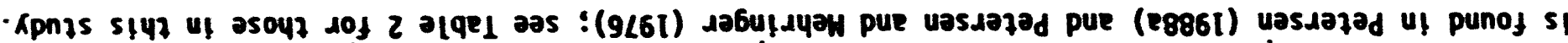

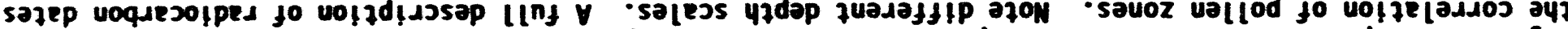

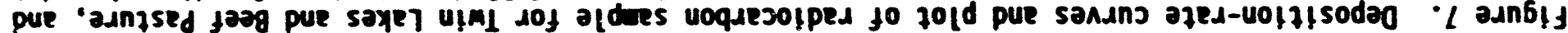

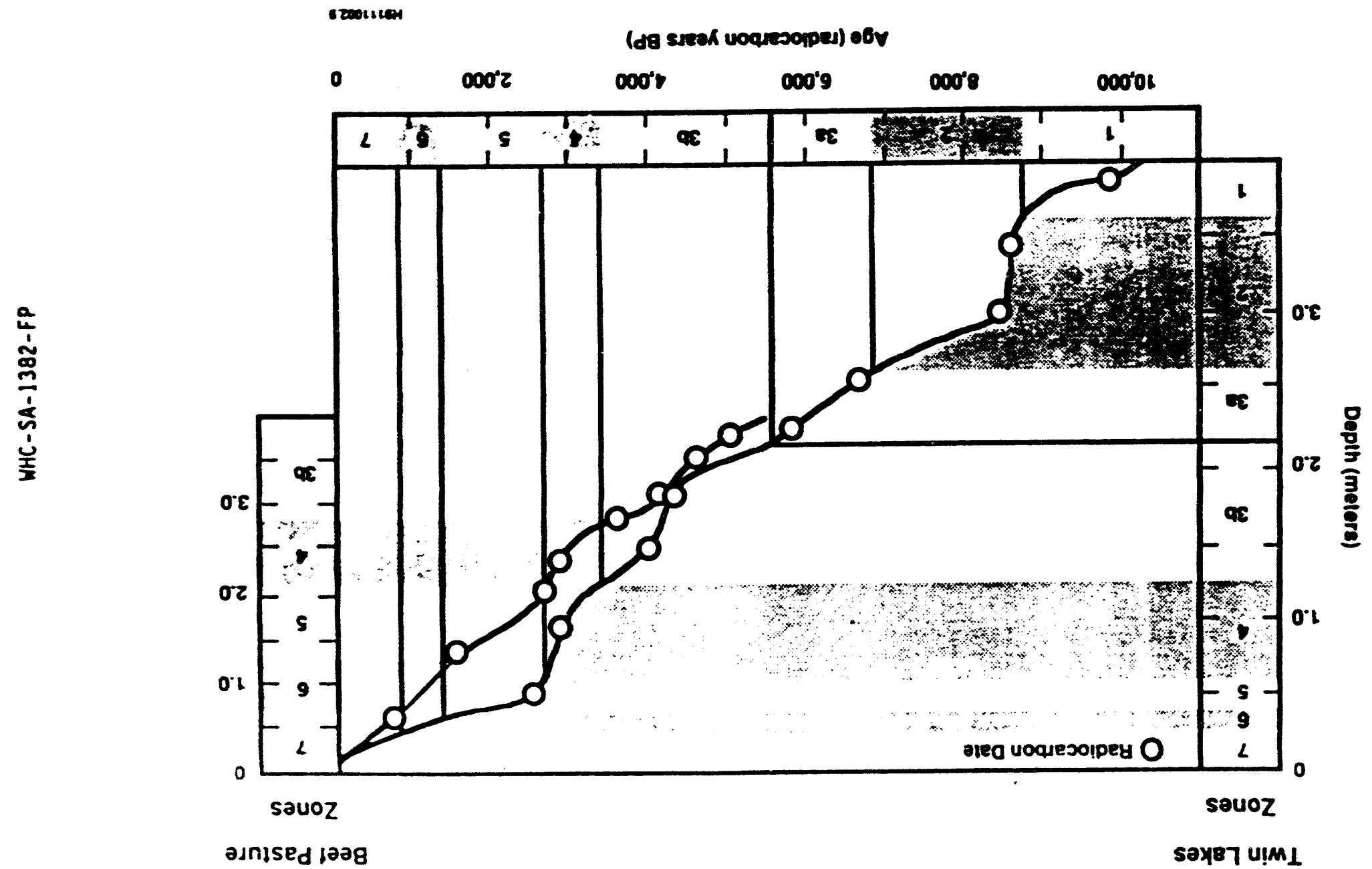


WHC-SA-1382-FP

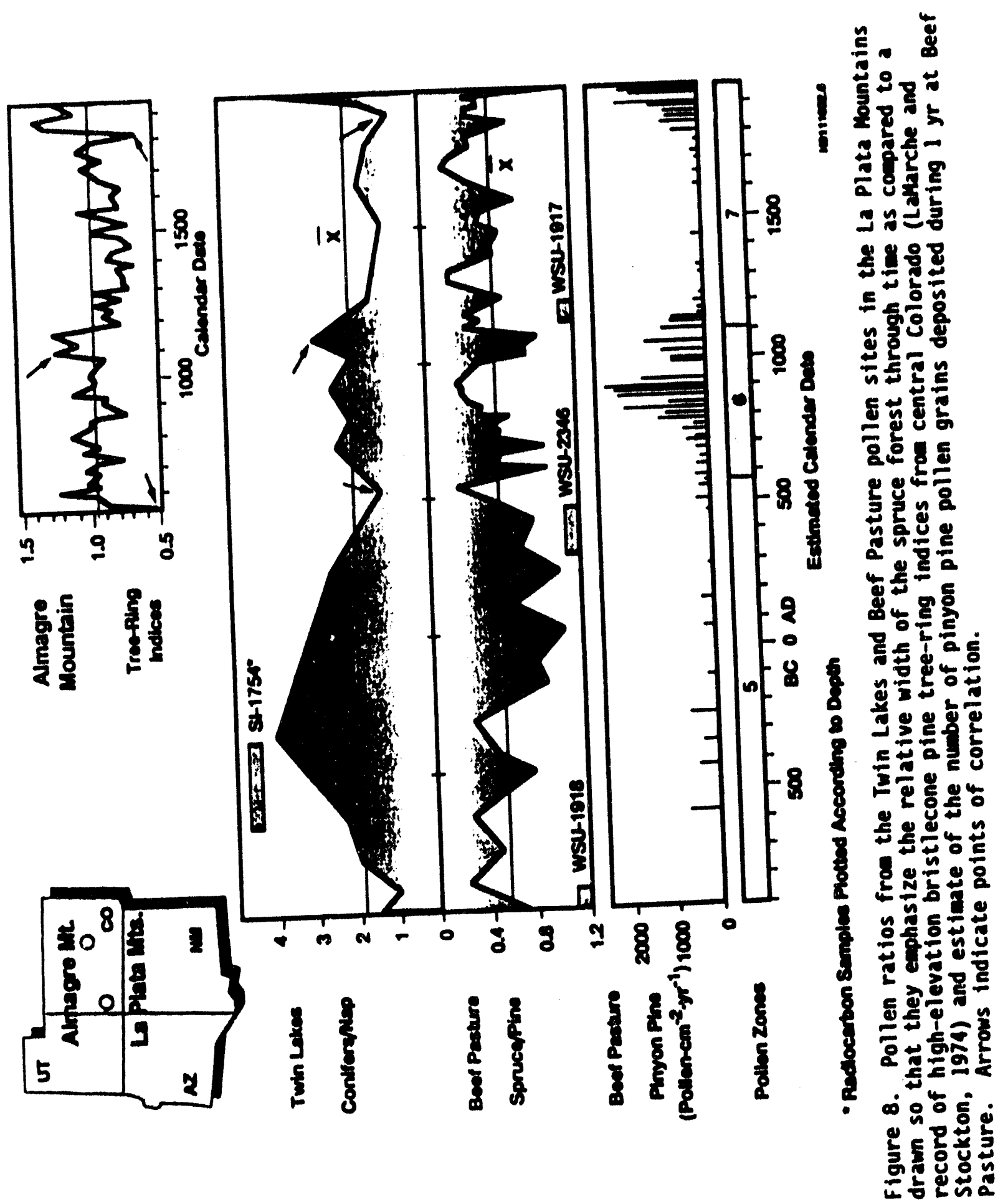


WHC - SA-1382-FP
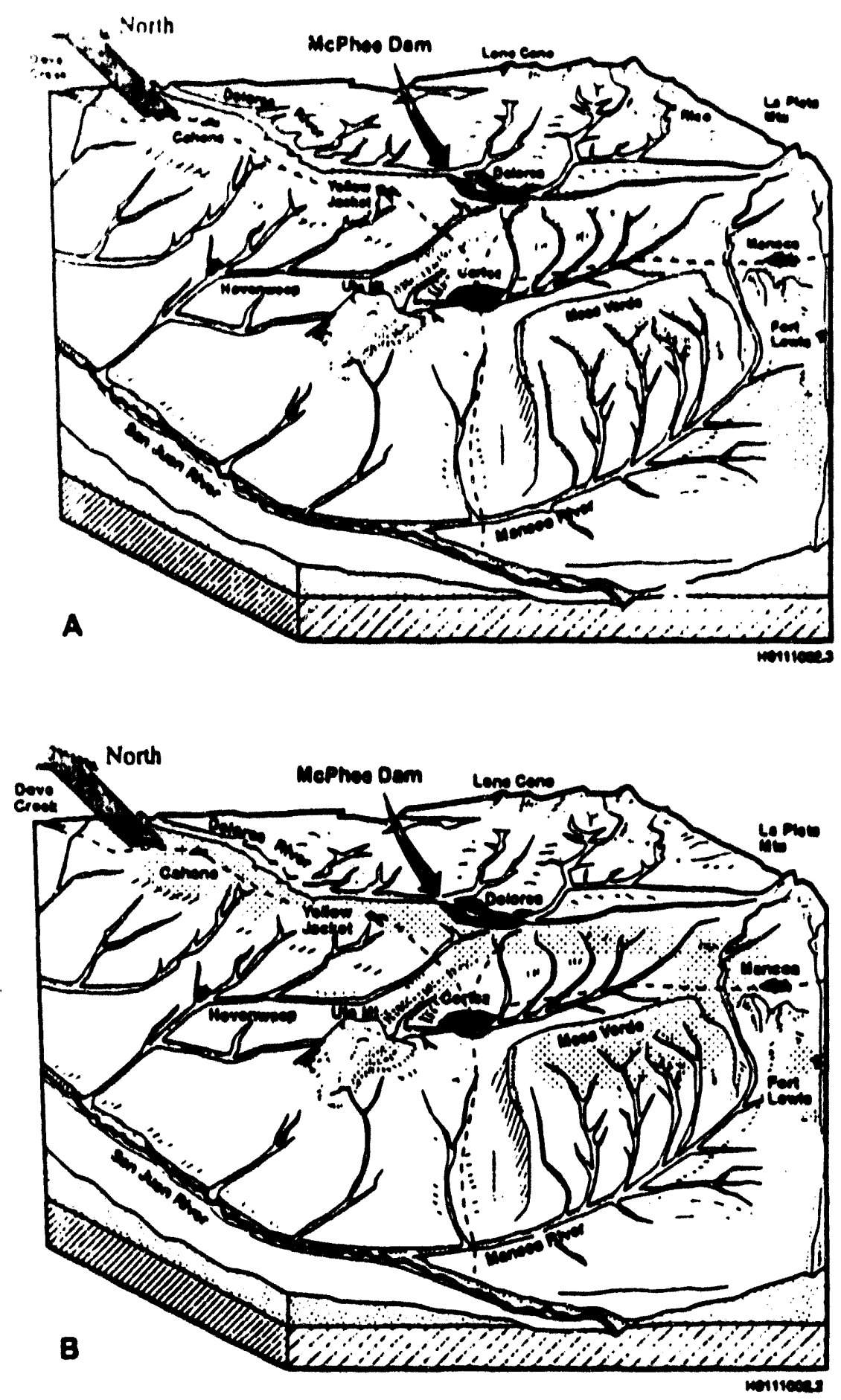

Figure 9. A bird's eye view or the reconstruction of the relative width of the potential dry-farm belt in southwestern Colorado. (A) Modern and $A D 600-800$, (B) $A D 800-1000$ and $1100-1300$. 
WHC - SA-1382-FP
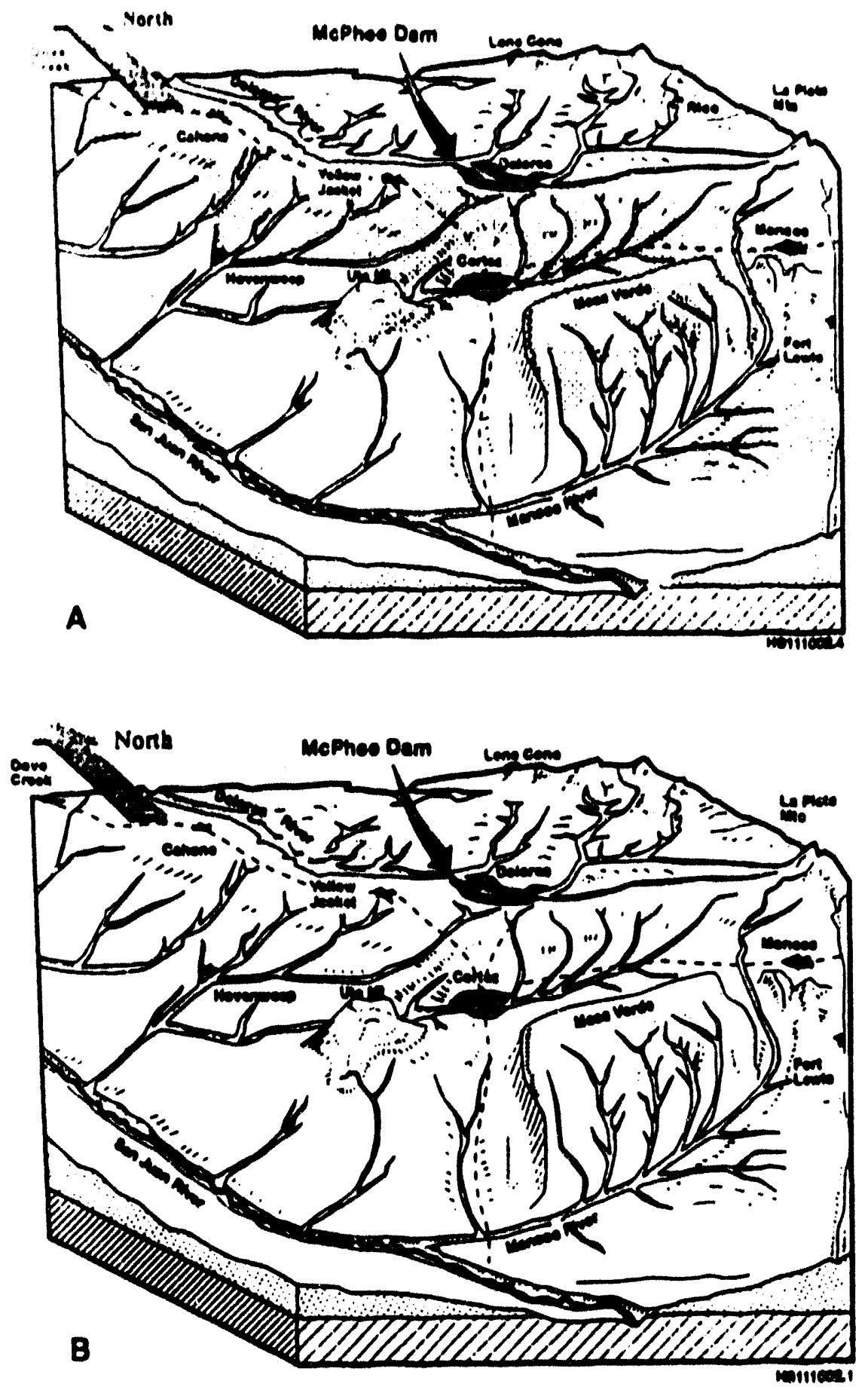

Figure 10. A bird's eye view or the reconstruction of the relative width of the potential dry-farm belt in southwestern Colorado. (A) $A D 1000-1100$, (B) AD $1300-1850$. 
WHC-SA-1382-FP

IAts1: 1: Climatlc summary (1951-1980) for 14 weather statlons in southwestern color ddo and southeastern Utah shown in Figure 1 .

\begin{tabular}{|c|c|c|c|c|}
\hline Station Name & $\begin{array}{l}\text { Elevation } \\
\text { (m) }\end{array}$ & $\begin{array}{l}\text { Annual } \\
\text { Preclp- } \\
\text { ltation } \\
\text { (cm) }\end{array}$ & $\begin{array}{l}\text { Mean } \\
\text { January } \\
\text { Temper- } \\
\text { ature } \\
\text { (CC) }\end{array}$ & $\begin{array}{l}\text { Mean } \\
\text { July } \\
\text { Temper- } \\
\text { ature } \\
\text { (C) }\end{array}$ \\
\hline Silverton, Co & 2,842 & 56.59 & -8.6 & 13.3 \\
\hline $\mathrm{RiCO}, \mathrm{CO}$ & 2,695 & 66.57 & 1 & 1 \\
\hline relluride, co & 2,669 & 54.79 & -5.7 & 15.4 \\
\hline Fort Lewis, Co & 2,315 & 44.78 & -5.4 & 18.1 \\
\hline Mesa Verde, CO & 2,155 & 44.55 & -1.6 & 22.6 \\
\hline Mancos, $\mathrm{CO}$ & 2,140 & 40.51 & 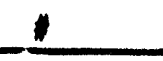 & 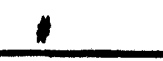 \\
\hline Monticello, UT & 2,128 & 36.60 & -3.9 & 20.3 \\
\hline Dolores, CO & 2,118 & 45.90 & $n$ & $\bullet$ \\
\hline Yellow Jacket 2W, co* & 2,091 & 37.80 & -4.6 & 21.4 \\
\hline Northdale, co & 2,040 & 30.58 & -5.2 & 20.3 \\
\hline Durango, $\mathrm{CO}$ & 1,996 & 47.27 & -3.5 & 20.2 \\
\hline Cortez, CO & 1,883 & 31.17 & -2.8 & 22.16 \\
\hline Blanding, UT & 1,868 & 29.72 & -2.6 & 23.1 \\
\hline Bluff, UT & 1,315 & 19.33 & -1.3 & 25.6 \\
\hline
\end{tabular}

Ttation records precipitation only

* For years 1962-1979 
WHC-SA-1382-FP

Tabl: 11: Radiocarbon dates presented in this study.

\begin{tabular}{|c|c|c|c|c|}
\hline $\begin{array}{l}\text { Depth } \\
\text { (m) }\end{array}$ & $\begin{array}{l}\text { Labora- } \\
\text { tory } \\
\text { Number }\end{array}$ & $\begin{array}{l}\text { Date } \\
(y r \\
\text { B.P.) }\end{array}$ & $\begin{array}{l}\text { Calibrated } A D / B C \\
\text { Age, I SD. } \\
\text { min'(Cal age) max }\end{array}$ & $\begin{array}{l}\text { Cal ibrated AD/BC Age, } \\
\text { I SD, } \\
\text { min (cal age) max** }\end{array}$ \\
\hline $\begin{array}{l}0.500- \\
0.550 \\
\end{array}$ & HSU- 1917 & $780 \pm 90$ & AD $1075(1170) 1264$ & $A D 1169(1259) 1281$ \\
\hline $\begin{array}{l}1.175- \\
1.275\end{array}$ & WSU-2346 & $1,540 \pm 80$ & AD $327(410) 493$ & $A D 420(539) 605$ \\
\hline $\begin{array}{l}2.000 \\
2.050\end{array}$ & WSU-1918 & $2,680 \pm 80$ & $B C 812(730) 647$ & BC $910(828) 801$ \\
\hline
\end{tabular}

\begin{tabular}{|c|c|c|c|c|}
\hline $\begin{array}{l}\text { Depth } \\
\text { (m) }\end{array}$ & $\begin{array}{l}\text { Labora- } \\
\text { tory } \\
\text { Number }\end{array}$ & $\begin{array}{l}\text { Date } \\
(y r \\
\text { B.P.) } \\
\end{array}$ & $\begin{array}{l}\text { Calibrated } A D / B C \\
\text { Age, } 1 \text { SD } \\
\text { min (Cal age) max }\end{array}$ & $\begin{array}{l}\text { Calibrated AD/BC Age, } \\
1 \text { SD } \\
\text { min (cal age) max }\end{array}$ \\
\hline $0.40-0.49$ & $51-1754$ & $2545+75$ & $B C 685(595) 505$ & BC $805(790) 543$ \\
\hline
\end{tabular}

Sagehen Marsh Radiocarbon Date

\begin{tabular}{|l|l|l|l|l|}
\hline $\begin{array}{l}\text { Depth } \\
(m)\end{array}$ & $\begin{array}{l}\text { Laboratory } \\
\text { Number }\end{array}$ & $\begin{array}{l}\text { Date } \\
\text { (yr B.P.) }\end{array}$ & $\begin{array}{l}\text { Cal lbrated AD/BC } \\
\text { Age, 2 SD } \\
\text { min - max }\end{array}$ & $\begin{array}{l}\text { Cal lbrated AD/BC } \\
\text { Age, 1 SO } \\
\text { min (cal age) } \\
\text { max }\end{array}$ \\
\hline $1.42-1.61$ & Beta-3058 & $1350+60$ & AD $585-785$ & AD $643(661) 682$ \\
\hline
\end{tabular}

* Stuiver and Reimer (1986)

**klein et al., (1982) 
WHC-SA-1382-FP

\section{DISTRIBUTION}

Number et covies

\section{EOREIGN}

1

Environmental Sciences Group

Intera-Exploration

Consultants, Ltd.

Highlands Farm, Grey Road

Henlyey-on-Thames

Oxon RG94PS

England

G. M. Smith

Department of Geography

University of Western Ontario

London, Ontario

N6A $5 \mathrm{C2}$

Canada

Dr. B. H. Luckman

OFFSIIE

1

U.S. Geological Suryey-MS 915

345 Middlefield Road

Menlo Park, CA 94025

Dr. D. P. Adam

1

Arizona-Sonoran Desert Museuta

Rt. 9, Box 9

Tucson, AZ 85743

Dr. T. R. Van Devender

1

Dames and Moore

Suite 108

4220 S. Mayl and Park Way

Las Vegas, NV 89119

Or. W. G. Spaulding

1

Department of Geography

University of California

Berkeley, CA 94720

Dr. R. Byrne

Distr-1 
WHC - SA-1382-FP

\section{DISTRIBUTION (cont)}

Number of sooles

1

Department of Forest Ressurces

University of Minnesota

115 Green Hall, MPS/CPSU

St. Paul, Mu 55108

Or. K. L. Cole

1

Scriops Inste of Ocernograhy

A-0224, Univ. of CA-San Diego

La Jolla, CA 92093-0224

D. Cayan

3

Geosciences Department.

University of Arizona

Bidg. 77

Tucson, AZ 85721

Or. 0. K. Davis

Dr. P. S. Martin

P. Van de Water

1

Department of Atmospheric Science

Creighton University

Omaha, NE 68178-0110

Dr. A. V. Douglas

1

Iree-Ring Laboratory

Lamont-Doherty Geol. Observ.

Palisades, NY 10964

Dr. G. C. Jacoby

1

MPS-Halenkala Mat' ' Park

P.0. Box 369

Makawao, Maul, HI 96768

Dr. L. L. Loope

l

Mestern Regional Climate Center

Desert Research Institute

P.0. Box 60220

Reno, NV 89506-0220

Dr. K. Redmund

Distr-2 
WHC -SA-1382-FP

Distrisuriow (cont)

Number of cooles

3

Secill Science Center

Desert Research Institute

P.0. Box 60220

Reno, NV 60220

F. M. Nials

Or. L. C. Pippin

Dr. P. E. Higand

1

Departmant of Systemtic Ecology

University of Kansas

Lawrence, Kansas 66045

Dr. P. V. Hells

1

Illinols state Yater Sw . ay

2204 Griffith Dr.

Champalgn, IL 61820

Dr. W. M. Wendland

2

U.S. Geological Suryey

1675 H. Anklam Road

Tucson, AZ 85745

Dr. J. 1. Betancort

Or. R. H. Hebb

2

Botany and Range Science Denartment

Brighan Young University

401 HIDB

Provo, Utah 84602

Dr. H. M. Hess

Dr. K. T. Harper

1

Chem-Nuclenr Geotech

P.0. Box 14000

Grand Junction, CO 81502

Dr. H. J. Waugh 
WHC-SA-1382-FP

OIstriaution (cont)

Number 21 ceoles

1

5

1

1

1

1

Beynelds Electrical Engineering Co. In P.0. Box 98521

Las Vegas, NV 89193-8521

Or. L. E. Barker

Department of Anthropology

Washington State University

Pullman, HA 99164

Dr. G. L. Gamble

Dr. F. A. Hassan

Dr. T. A. Kohler

Dr. W. A. Lipe

Dr: P. J. Mehringer

Geologr Department

Washington State University

Pullman, HA 99164

Dr. D. Gaylord

Aaronomy Degartment

Washington State University

Pullman, Washington 99164

Dr. A. J. Busacca

Dr. G. S. Campbell

Goddard Institute for space studies

2880 uroadway

New York, NY 10025

Dr. D. H. Rind

EBASCO

Richland, WA 99352

R. Treat

V.S. Geological Survey

MS 432

Reston, VA 22092

I. j. Winograd

Distr-4 
WHC-SA-1382-FP

OISTRIBUTION (cont)

Number af coofes

1

Paleotology and Stritloriohy Arinch

Geological Survey

U.S. Department of Interior

Box 25046, M.S. 919

Denver Federal Center

Denver, CO 80225

Dr. R. S. Thompson

2

Department of Geearaphy-Geology

Geological Survey

U.S. Department of Interlor

Box 25046, M.S. 913

Denver Federal Center

Denver, CO 80225

Dr. P. E. Carrara

Or. R. R. Shroba

1

Los Alamos National Laboratory

P.0. Box 1663, MS J495

Los Al amos, NM 87545

Or. T. E. Hakonson

1

Jacobs Engineering Group. Inc.

5301 Central Avenue N.E.

Suite 1700

Albuquerque, NM 87108

Dr. C. Reith

1

Sandia Mational Laborateries

P.0. Box 5800

Aibuquerque, NM 87185

J. Phelan

1

Idahe Mational Enainearing Laboratory

P.0. Box 1625

Idaho Falls, ID 83415

K. Merrill 
$W H C-S A-1382-F P$

DISTRIBUTION (cont)

Number uf soples

Bandelter Mattonal Monument

HCR 1, Box 1, Sulte 15

Los Al amos, NM 87544-9702

C. Allen

1

Department of Geology

University of New Mexico

Albuquerque, NM 87131

Dr. R. Y. Anderson

2

Bibly Research Center

Northern Arizona University

Box 6013

Flagstaff, AZ 86011

Dr. R. S. Anderson

Or. J. I. Mead

1

Department of Biological Sclences

Northern Arizona University

Flagstaff, Arizona 86001

Dr. R. H. Hevly

1

Anthropology Department.

Eastern New Mexico Untversity

Portales, N 88130

Dr. R. G. Holloway

1

Intermountain Forest and Range Experiment station

U.S. Department of Agriculture

Forest Service

Northern Forest Fire Laboratory

Orawer 6

Missoula, Montana 59806

Dr. S. Arno

1

CIRES/Department of Geoariohy

University of Colorado

Boulder, CO 80309

Dr. R. G. Barry

Distr-6 
Number of noples

INSTAAB

Untversity of Colorado

Box 450

Boulder, CO 80309-450

Dr. V. Markgraf

Dr. H. Nichols

Dr. S. K. Short

3

Department of Anthropology

Universit:. of Colorado

Boulder, CO 80309-0233

Dr. F. W. Eddy

Or. P. D. Sheets

Or. R. H. Wilshusen

1

Department of Geeleay

University of Iowa

lowa City, Iowa 52242

Or. R. G. Baker

2

Department of Geoaraphy

University of Oregon

Eugene, OR 97403

Dr. P. J. Bartlein

Or. C. Whitlock

1

Ward Center for Mountain Research

Overland Road, Star Route

Ward, Colorado 80481

Dr. J. B. Benedict

Mess Verde Regional Resenrch Center

P.0. Box 592

Dove Creek, CO 81324

Dr. D. A. Breternitz 
WHC - SA-1382-FP

DISTRIBUTION (cont)

Numbar of repies

2

Department of Range Sclence

Utah State University

Logan, Utah 84322

Dr. M. M. Caldwell

Dr. N. E. Hest

7

Laboratory of Iree-Ring Bessearch

University of Arizona

Butlding 58

Tucson, AZ 85721

Dr. J. S. Dean

Or. H. C. Fritts

Dr. L. J. Graumlich

Dr. K. K. Hirschboeck

Dr. M. Hughes

Dr. C. H. Stockton

Dr. M. A. Stokes

1

Colorado Climate Center

Department of Atmospheric Science

Colorado State University

Fort Collins, CO 80523

N. J. Doesken

1

Division of Historic Preservation and Archneology

123 W. Nye Lane, Room 1208

Capitol Complex

Carson City, NV 89710

Dr. E. M. Hattori

1

Department of Geography

Arizona State University

Tempe, AZ 85287

Dr. P. L. Fall

1

Department of Anthropology

Arizona State University

Tempe, AZ 85281

Dr. J. Schoenwetter

Distr-8 
WHC-SA-1382-FP

DISTRIBUTION (cont)

Wimber of coples

1

1

Bureau of Land Management
Moab District

P.0. Box 970

Moab, UT 84532

B. D. Louthan

Nature Conservancy

P.0. Box 11486

Salt Lake City, UT 84147

Dr. N. S. Van Pelt

\section{ONSITE}

6

\section{U.S. Department of Eneray-}

Richland Oparntions Office
K. W. Bracken
M. J. Furman
J. D. Goodenough
J. M. Hennig
J. R. Hunter
C. R. Pasternak

Pacific Northwest Laboratory
D. J. Bradley
L. L. Cadwell
M. D. Campbell
J. C. Chatters
J. L. Downs
M. J. Fayer
M. G. Foley
H. D. Freeman 
Number ol corles
G. W. Gee (2)
C. T. KIncala
M. H. llgotke
S. 0. LInk
M. E. Peterson
W. H. Rlckard
M. L. Rockhold
L. L. Rogers
S. C. Slate
D. L. Stewart
T. L. Stewart
G. M. Stokes
M. E. Thiede
H. H. Walters

KG-11

K6-11

P7. 54

P7.54

F7-41

P7-54

K6-77

P7-54

$K \perp-25$

K6-91

KI-25

KI-74

P7 -54

K6-77

Mest inghouse Hanford Company

M. R. Adams

J. D. Berger

L. C. Brown

J. W. Cammann

D. L. Crockford

J. I. Dearing

K. R. Fecht

T. E. Gates

R. L. Gilchrist

F. N. Hodges

G. W. Jackson

C. J. Kemp

D. S. Landeen

R. E. Lerch

R. M. Mitchell

D. R. Myers

K. L. Petersen (15)

S. J. Phillips

R. H. Powell

S. P. Reidel

M. R. Sackschewsky

K. R. Simpson

J. C. Sonnichsen

J. A. Voogd

S. Weiss

N. R. Hing (2)

Central files (3)
H4-55

L0-18

H4-51

$\mathrm{H} 4-14$

H4-17

H5- 58

H4-56

[5-63

L5-63

H5-29

B2-35

H4-14

H4-14

H2-35

H4 -55

H4-14

H4-14

H4-14

H4-14

H5-29

H4-14

H5-29

H4-14

R4-03

H4-55

H4-14 

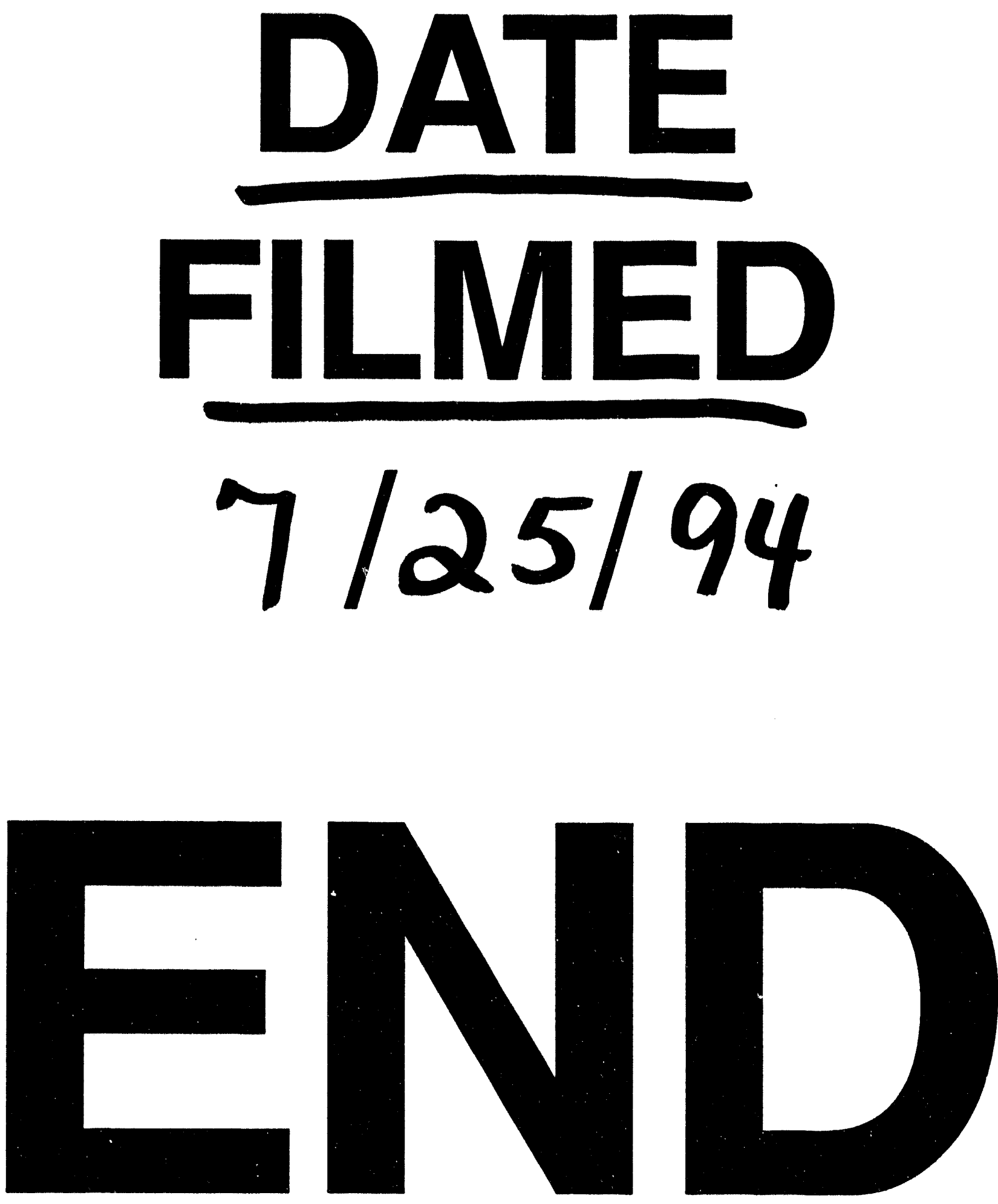
